\title{
The Genetics of Autism
}

\author{
Deborah K. Sokol and Debomoy K. Lahiri
}

This chapter is written to make the fast-paced, expanding field of the genetics of autism accessible to those practitioners who help children with autism. New genetic knowledge and technology have quickly developed over the past 30 years, particularly within the past decade, and have made many optimistic about our ability to explain autism. Among these advances include the sequencing of the human genome (Lander et al., 2001) and the identification of common genetic variants via the HapMap project (International HapMap Consortium, 2005), and the development of cost-efficient genotyping and analysis technologies (Losh, Sullivan, Trembath, \& Piven, 2008). Improvement in technology has led to improved visualization of chromosomal abnormality down to the molecular level. The four most common syndromes associated with autism include fragile $\mathrm{X}$ syndrome, tuberous sclerosis, $15 \mathrm{q}$ duplications, and untreated phenylketonuria (PKU; Costa e Silva, 2008). FXS and $15 q$ duplications are discussed within the context of cytogenetics. TSC is illustrated within the description of linkage analysis.

As recently reviewed ( $\mathrm{Li} \&$ Andersson, 2009), the first inkling of chromosomal anomaly causing clinical pathology occurred in 1959 when an extra copy of chromosome 21 was associated with the Down syndrome phenotype. Shortly thereafter, chromosomal abnormality was recognized for Patau's syndrome (trisomy 13) and Edward's syndrome (trisomy 18). The chromosomal banding technique developed in 1970 led to the identification of many structural chromosomal abnormalities associated with clinical conditions. The discovery that genes located close to each other on a chromosome are often inherited together led to linkage analysis in the 1970s and 1980s. Linkage techniques related chromosomal abnormalities with known genetic anomalies using

D.K. Sokol ( $\square)$

Department of Neurology, Riley Hospital for Children, Indiana University School of Medicine, Indianapolis, IN 46202, USA

e-mail: dksokol@iupui.edu an affected sibling-pair design in multiplex (having more than one affected member) families. This led to the identification of chromosomal abnormalities in such conditions as neurofibromatosis, tuberous sclerosis, and dyslexia (Smith, 2007). Improving technology in the 1990s enabled the detection of small genomic alterations of $50-100 \mathrm{~kb}$ and the direct visualization of these alterations in uncultured cells via fluorescent in situ hybridization (FISH). This technique ushered in the field of molecular genetics (Li \& Andersson, 2009) and allowed the identification of chromosomal microdeletions and duplications in areas of the chromosome where there is already high suspicion that abnormality would exist. FISH enables prenatal and cancer genetics screening and has led to the identification of genetic aberrations associated with Angelman's and Prader Willi syndromes.

In the past decade, microarray cytogenetics has permitted the study of the entire genome on a single chip with resolution as fine as a few hundred base pairs ( $\mathrm{Li} \&$ Andersson, 2009). Such microarray technology represents a union between molecular genetics and classical cytogenetics. Two types of microarray technology are used clinically: comparative genomic hybridization $(\mathrm{CGH})$ and single-nucleotide polymorphism (SNP) analysis. CGH directly measures copy number differences between a patient's DNA and a normal reference DNA spanning known genes, chromosomal regions, or across the entire genome. SNP analysis, on the other hand, provides identification of a single point mutation via sequencing the gene in areas of suspected abnormality, previously identified via CGH or FISH. Another offshoot of microarray technology is submicroscopic chromosome copy number variation (CNV) analysis, in which deletions or duplications involving $>1-\mathrm{kb}$ DNA have been detected in patients with mental retardation, autism, and multiple congenital anomalies.

There are several recent, detailed reviews of the genetics of autism (Abrahams \& Geschwind, 2008; Li \& Andersson, 2009; Losh et al., 2008; O'Roak \& State, 2008) and this chapter summarizes those reviews. The reader is encouraged to first review the overview of gene expression (Box 6.1) and 
essential nomenclature used in genetics (Box 6.2). In addition, one must understand basic concepts pertinent to brain development (Box 6.3) and to the neurobiology of autism (Box 6.4) in order to understand its genetics. For example, there is a compelling rationale that genetically directed mechanisms that regulate the assembly of the brain during embryogenesis, when gone awry, may cause autism (Costa e Silva, 2008).

\section{Box 6.1 Overview of DNA Replication and Gene Expression*}

Genes. A gene is a unit of hereditary material located in a specific place (locus) on a chromosome. Most genes carry the instructions for producing a specific protein. A protein-coding human gene will have a coding sequence, which contains the information for protein production. The coding sequence may be broken up into several sub-sequences, or exons, which are separated by noncoding DNA sequences, or introns. The coding sequence is flanked by a promoter and (usually) a $5^{\prime}$-untranslated region $\left(5^{\prime}\right.$-UTR) that occur immediately before the coding sequence and by a $3^{\prime}$-UTR and a terminator that occur immediately after the coding sequence. Promoters, terminators, UTRs, and introns can regulate the activity of a given gene. At a molecular level, chromosomes are composed of long chains of deoxyribonucleic acid (DNA) upon which genes are linearly arranged. The DNA exists in a double helix and the helical strands are usually wrapped around histone proteins. In addition to DNA and histones, chromosomes contain scaffolding proteins that provide structural support and may also participate in gene regulation. DNA is a molecule composed of a chain of four different types of nucleotides. It is the sequence of these nucleotides that is the genetic information that organisms inherit. DNA is double stranded with nucleotides on each strand complementary to each other. Each strand acts as a template for creating a new partner strand. This is the physical method for making copies of genes that are inherited. Both individual DNA nucleotides and DNAassociated proteins can be chemically modified to produce epigenetic variation that may be in response to environmental conditions and might or might not be inherited in any individual case. Epigenetic variation can significantly alter the expression level of a gene without changing its basic genetic code.

DNA replication. During DNA replication, a DNA strand is produced from component nucleotides using its partner strand as a template. This is done by DNA polymerases that "proofread" to ensure accuracy and repair when necessary. Despite these safeguards, errors called mutations can occur during the polymerization of this second strand. A mutation is any nucleotide sequence in a DNA molecule that does not match its original DNA molecule from which it is copied. Radiation, such as ultraviolet rays and X-rays, viruses, and errors that occur during meiosis or during DNA replication can cause errors in DNA molecules. These mutations can have an impact on the phenotype of an organism, especially when they occur within the protein-coding sequence of the gene. Kinds of mutations include the following:

Frameshift Mutation: One or more bases are inserted or deleted. This can alter the entire amino acid sequence of a protein or introduce aberrant RNA splicing.

Deletion. Missing DNA sequences can range from a single base pair to longer deletions involving many genes in the chromosome.

Insertion. Additional nucleotides are inserted in the DNA sequence and can result in a nonfunctional protein.

Duplication (or gene amplification). Multiple copies of a complete gene or genes, increasing the dosage of genes located within chromosomes.

Inversion. DNA sequence of nucleotides is reversed, either among a few bases within one gene or among longer DNA sequences containing several genes.

Point mutations. Known as substitutions, this is a replacement of a single base nucleotide with another nucleotide.

Missense mutations. A point mutation where a single nucleotide is changed to cause substitution of a different amino acid.

Nonsense mutation. A point mutation that results in a premature stop codon in the transcribed mRNA and possibly a nonfunctional protein product.

RNA splicing mutation. A point mutation that inserts or deletes an intron/exon border necessary for splicing of heterogeneous nuclear RNA to mRNA.

Silent mutation. A point mutation that does not alter the amino acid coding for that codon.

Gene expression is the process in which genes express their functional effect through the production of proteins which are responsible for most functions of the cell. The DNA sequence of a gene is used to produce a specific protein through a ribose nucleic acid (RNA) intermediate. Gene DNA is the map 
which directs the production of the protein, normally following a one-way pathway:

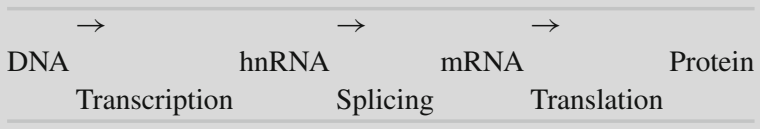

Gene regulation gives the cell control over structure and function and is the basis for cellular differentiation and adaptability of any organism. Gene regulation is controlled by noncoding DNA sequences, such as the promoter, terminator, or introns, and by epigenetic variation, such as differences in DNA methylation and histone acetylation. This entire process takes place within the cell in the vicinity of the nucleus, where DNA is housed and hnRNA is spliced, and in the cytoplasm, where ribosomes are located along the rough endoplasmic reticulum. Some proteins are further processed in the Golgi apparatus if they are to be exported from the cell. The correspondence between nucleotide and amino acid sequence is known as the genetic code.

RNA transcription. In transcription, DNA is used as a blueprint for the production of RNA. Transcription is performed by RNA polymerase which adds one ribonucleotide to a growing RNA strand, complimentary to the DNA nucleotide being transcribed. This product is heterologous nuclear RNA (hnRNA).

RNA splicing. In splicing, hnRNA is processed within the nucleus to remove introns which may function to partially regulate transcription and join exons, which code for the actual protein product. The product of slicing is mRNA.

Translation. Translation is the production of proteins by decoding the mRNA that was produced by transcription and splicing. The mRNA sequence is the template that guides the production of a chain of amino acids that form a protein.

*Pack (2002)

\section{Box 6.2 Genetic Terms**}

Allele. This is an alternate DNA sequence at the same physical gene locus which may represent different phenotypes. For example, for ABO blood type, there are three alleles, $\mathrm{I}^{0}, \mathrm{I}^{\mathrm{A}}$, and $\mathrm{I}^{\mathrm{B}}$. Any individual has one of six genotypes $(\mathrm{AA}, \mathrm{AO}, \mathrm{BB}, \mathrm{BO}, \mathrm{AB}$, and
OO) that produce four phenotypes: "A" (produced by AA homozygous and $\mathrm{AO}$ heterozygous genotypes), "B" (produced by BB homozygous and BO heterozygous genotypes), "AB" heterozygotes, and "O" homozygotes.

Association Study. A test to determine whether a particular variant (allele) of a marker or a gene occurs more frequently in those with the disorder than in those without the disorder. It detects effects in much smaller regions of the genome than linkage.

Comparative genomic hybridization (CGH). A microarray technique that directly measures copy number differences between a patient's DNA and a normal reference DNA spanning known genes, chromosomal regions, or across the entire genome.

Copy number variation $(C N V)$ analysis. This technique is an offshoot of microarray technology in which 0 , 1 , or 3 copies, defined as deletions or duplications involving $>1 \mathrm{~kb}$ DNA, are detected in patients with mental retardation, autism, and multiple congenital anomalies.

Cytogenetics. Study of the structure and function of a cell as it relates to the chromosomes

Fluorescent in situ hybridization (FISH). This is a molecular genetic technique which allows direct visualization of microdeletions and duplications of $50-100 \mathrm{~kb}$ of a specific chromosome region in uncultured cells. FISH has enabled prenatal screens for chromosomal abnormality and developmental conditions such as Angelman's and Prader Willi syndromes and postnatal screening for cancer. FISH can only probe specific sequences that are known and suspected to be associated with known syndromes.

Genome. The full set of hereditary material in an organism - usually the combined DNA sequences of all chromosomes. Genome-wide association studies (GWAS) compare genetic risk factors in the form of specific genetic markers in cases and controls. These markers are distributed across the entire genome rather than limited to specific gene regions such as in the sib-pair method.

Genotype: A pair of two alleles which can be the same (homozygous) or different (heterozygous). Genotype interactions between the two alleles at a locus can be dominant (where the heterozygote is indistinguishable from one of the homozygotes), recessive (the allele which is under expressed if mixed with a dominant allele), semi-dominant (where the heterozygote resembles the homozygote dominant more than it does the homozygote 
recessive but does not have the full homozygote dominant trait), or co-dominant (when both alleles contribute equally to a phenotype that is distinct from either homozygote). In the case of human blood types, for example, $\mathrm{I}^{\mathrm{A}}$ and $\mathrm{I}^{\mathrm{B}}$ are each dominant over $\mathrm{I}^{0}$, while $\mathrm{I}^{\mathrm{A}}$ and $\mathrm{I}^{\mathrm{B}}$ have co-dominance with each other.

Linkage Study. A test to determine where genetic markers are inherited along with a given disorder. When genes are located together on a chromosome, they are often inherited together. Finding a marker linked to a disorder gives the approximate location of a risk gene for that disorder. In the sib-pair linkage study method, siblings with autism are evaluated to determine whether they share any region of the genome more frequently than would be expected by chance.

Mendelian locus. A single gene variant sufficient to completely explain a phenotypic trait, such as a disorder. Examples of pathogenic variations or mutations of single genes include PKU, sickle cell, and Angelman's syndrome.

Mendelian transmission. A condition that is inherited via autosomal dominant, recessive, or sex-linked transmission.

Microarray technology. Developed within the last decade, this technique enables examination of the whole human genome on a single chip with a resolution as high as a few hundred base pairs. This resolution is at least 10 -fold greater than the best prometaphase chromosomal analysis and therefore, it is the most sensitive for whole genome screen for deletions and duplications.

Penetrance. The proportion of individuals carrying a particular variation of a gene that also expresses an associated trait. For example, if a mutation has $95 \%$ penetrance, then $95 \%$ of those with the mutation will develop the syndrome, while $5 \%$ will not.

Quantitative trait locus (QTL). A gene variant that is expressed along a continuous phenotype, whose extreme end may produce the disorder such as hypertension, reading disability, or attention-deficit disorder with hyperactivity (ADHD).

Recessive genetic disorders. A number of genetic disorders are caused when an individual inherits two recessive alleles for a single gene trait, such as with cystic fibrosis, PKU, or albinism. Recessive alleles can be located on the $\mathrm{X}$ chromosome so that males are more affected than females (hemizygous), such as in fragile $\mathrm{X}$.
Single-nucleotide polymorphism (SNP) analysis. A microarray technique that identifies a single point mutation via sequencing the gene in areas of suspected abnormality as identified via CGH or FISH. This looks at a smaller region with greater detail than does CGH.

**Solomon, Berg, and Martin (2008)

\section{Box 6.3 Normal Brain Development}

During embryologic development, the brain emerges from the neural tube, an early embryonic structure. The anterior neural tube expands rapidly due to cell proliferation and eventually gives rise to the brain. Cells stop dividing and differentiate into neurons and glial cells, the main cellular components of the brain. The neurons must migrate to different parts of the developing brain to self-organize into different brain structures. The neurons grow connections (axons and dendrites) which often must span long distances to reach their target cells. Growth cones are the highly motile filamentous connections that eventually form more stable synapses between neurons. Neurons communicate with other neurons via these synapses. This communication leads to the establishment of functional neural circuits that mediate sensory-motor processing and behavior.

Associated with this period of synaptogenesis is a brief period of "programmed" cell death, a pruning process in which cells succumb during natural development (Mattson \& Furukawa, 1998). Migration of cells from the ventricular zone lining the central canal of the neural tube to the developing cortex next takes place followed by a more protracted period of pruning (Volpe, 2001). One mechanism that allows cells to detach and migrate away from each other appears to be regulated by a "molecular switch" regulated by catenin adhesion proteins (DiCicco-Bloom, 2006). Neuroligin, recently described in autism research, is a cell adhesion molecule found in the postsynaptic membrane. Also, brain-derived neurotrophic factor (BDNF) is produced by the brain and regulates several functions within the developing synapse, including enhancement of neurotransmitter release.

Activity at the CNS synapses occurs over the life span and is thought to underlie learning and memory. The excitatory neurotransmitter glutamate and its receptors, particularly the $N$-methyl-D-aspartate (NMDA) receptor, initiate synaptogenesis through activation of downstream products. At the CNS 
synapse, a nerve terminal is separated from the postsynaptic membrane by a cleft containing specialized extracellular material. Localized vesicles are at the active sites and clustered receptors are at the postsynaptic membrane with glial cells that encapsulate the entire synaptic cleft. There is differentiation of the pre- and postsynaptic membrane following initial contact between two cells. This includes the clustering of receptors, localized upregulation of protein synthesis at the active sites, and continued neuronal pruning through synapse elimination. Neurons within the CNS receive multiple inputs that must be processed and integrated for successful transfer of information. The multiple inputs physically represent the plasticity of the brain.

\section{Box 6.4 Neurobiology of Autism}

Macrocephaly has been one of the "most widely replicated biological findings in autism" (McCaffery \& Deutsch, 2005), affecting up to $20 \%$ of all children with autism. Several reports have shown increased brain volume (macroencephaly/megalencephaly) in both white and grey matter with results varying as a function of age. MRI volumetric studies have showed increased brain volume in younger (total ages 2-21) subjects compared to older (total ages 5-21) subjects (Courchesne, Carper, \& Akshoomoff, 2003; Sokol \& Edwards-Brown, 2004; Sparks et al., 2002). To explain the relevance of brain volume enlargement in autism, it has been proposed that brain "growth without guidance" occurs in young autistic children (Courchesne et al., 2001) with premature expansion and overgrowth of neural elements and dendritic connections. Indeed, brain enlargement appears to develop postnatally, arising before or during the early recognition of autistic behaviors - between 18 months and 3 years (Courchesne et al., 2003).

Proposed mechanisms underlying brain enlargement include overproduction of synapses, failure of synaptic pruning, excessive neurogenesis, gliogenesis, or reduction in cell death (McCaffery \& Deutsch, 2005). The mechanisms underlying the tremendous growth of the typically developing embryonic brain, compared to the relatively more limited postnatal and adult brain growth, have been implicated in the brain enlargement seen in autism. This leads to the proposal that overstimulation of nuclear receptor-mediated gene transcription may increase neural progenitor cells that generate marked increases in cortical surface area
(McCaffery \& Deutsch, 2005). Therefore, the number of neurons in the young cortex is a function of the number of proliferative cells present at the onset of neurogenesis. Tumor suppressor genes which control brain growth and migration, when defective, could contribute to macrocephaly of failure in synaptic pruning. This explains the great interest in tumor suppressor genes such as PTEN as candidate genes for autism.

Recently, neuronal cell adhesion has been proposed as another mechanism involved in brain overgrowth in autism. Cell adhesion suppresses brain growth, while abnormalities in adhesion promote growth or contribute to aberrant growth. It is believed that heterogeneous causes of autism may be associated with alterations in adhesion molecules of the synapse or cytoplasmic molecules associated with synaptic receptors. Indeed, recent genetic evidence has found associations between autism susceptibility and other neuronal cell adhesion molecules, such as NLGN1 and ASTN2 and specific cadherins.

There is an emerging theory, as recently reviewed in Geschwind (2009), that short-range brain connections may be overgrown and longer range brain connections between different brain lobules are reduced in autism. In autism, there has been a noted reduction in the size of the corpus callosum which connects the two cerebral hemispheres and reduced connectivity between the frontal and temporal lobes of the brain, locations responsible for language and social judgment. The preservation of normal short-range connections could explain some of the preserved processing functions such as visual perception or attention to detail experienced by many with autism (Geschwind, 2009).

\section{Indirect Evidence of Heritability}

Three lines of research indirectly attest to the heritability of autism: twin studies, family studies, and the fact that autism affects more boys than girls. In general, hereditability appears to be greater when a broader definition of autism (including individuals with cognitive deficits and/or social impairment) instead of the specific DSM-IV criteria for autism is used.

\section{Twin Studies}

In the first twin study of autism (Folstein \& Rutter, 1977), the concordance rate in monozygotic (MZ) pairs (36\%) was 
significantly greater than that found in dizygotic (DZ) pairs $(0 \%)$. If the phenotype was expanded to include a cognitive or a language disorder, the concordance rates were 82 and $10 \%$, respectively. Two subsequent studies found an MZ/DZ concordance rate of 91-0\% (Steffenburg et al., 1989) or $60-5 \%$ utilizing the specific phenotype, and $90 \%$ vs. $10 \%$ using the broader phenotype which included social or cognitive deficits (Bailey et al., 1995). Across twin studies of autism, the difference between MZ and DZ concordance rates is sizable, averaging roughly 10:1 (Pennington, 2009). This rate is greater than that for other psychiatric disorders such as depression, bipolar disorder, and schizophrenia (between 2:1 and 4:1), indicating a high heritability for autism (Pennington, 2009). On the other hand, there was great variability in IQ and clinical behaviors in the $16 \mathrm{MZ}$ pairs concordant for autism in the (Bailey et al., 1995) study. In other words, there was no more similarity for these traits within $\mathrm{MZ}$ pairs than that between individuals picked at random from different MZ pairs who also had autism. As interpreted by Pennington (2009), this finding suggests that although autism is heritable, the genes may not dictate the exact phenotype. Nonadditive interaction among genes (epistasis) and nonshared environmental influences likely contribute to these differences in phenotypes. Further, the large disparity between the MZ and the DZ concordance rates has been attributed to epistasis (Pennington, 2009). Alternatively, rare gene variants causing a common disorder (autism), as described below, could contribute to this large $\mathrm{MZ/DZ}$ discordance.

\section{Familiarity}

Individuals with autism rarely marry and have children so that vertical transmission of the diagnosis from parent to child is rarely observed (Pennington, 2009). However, genetic transmission is still possible as parents can transmit genetic risk factors without having the diagnosis themselves. Family studies (cited in Geschwind \& Konopka, 2009; Pennington, 2009) suggest that the risk of autism is 20-60\% higher in siblings compared to the incidence of autism in the general population, and to that of other psychiatric disorders. Several studies have shown that a broad autism phenotype is transmitted in families of individuals with autism (Piven, 1999; Rutter, 2000). For example, first-degree relatives of individuals with autism were shown to be shy, aloof, and have problematic pragmatic language (Rutter, 2000). This pattern is consistent with the segregation of sub-threshold traits within these families (Abrahams \& Geschwind, 2008).

\section{Gender Differences}

Finally, autism affects more boys than girls (4:1), a finding which has remained constant since Kanner's first description of autism in 1945, and despite the increasing incidence of this diagnosis. The predominantly male ratio has been attributed to an abnormality on the $\mathrm{X}$ chromosome (discussed below), or to sex linkage or genomic imprinting (Lintas \& Persico, 2009; Marco \& Skuse, 2006). Sex linkage involves a gene on the $\mathrm{X}$ chromosome transmitted from the mother to the son. As the son has only one $\mathrm{X}$ chromosome, this gene would be expressed. Since the mother's daughter has two copies of the $\mathrm{X}$ chromosome - one from her father and one from her mother - the daughter likely would not express the abnormal phenotype. The most well-known example of a sex-linked disorder is hemophilia, which is on the $\mathrm{X}$ chromosome. Genomic imprinting, on the other hand, is an epigenetic phenomenon wherein chemical modification of DNA that does not alter the basic DNA sequence or modification of the DNA-associated histone proteins determines whether the maternal or the paternal copy of a specific gene is expressed. Genomic imprinting has been determined for Prader Willi and Angelman's syndrome.

Finally, increased risk for autism has been identified in the offspring of older fathers (Reichenberg et al., 2006). Therefore, the gender and age of the parent may confer risk for offspring with autism.

\section{Genetic Models of Autism}

The conclusion drawn from indirect evidence is that autism is the most heritable and familial neurodevelopmental disorder (Pennington, 2009). With rare exceptions, however, autism does not appear to be the action of a single gene inherited in a strictly Mendelian pattern (autosomal dominant, recessive, or X-linked; Gupta \& State, 2007; O'Roak \& State, 2008). Rather, there are reports of multiple, distinctly rare changes in the genetic code in small subsets of individuals that cause or contribute to autism. There may be multiple gene variants - "a conspiracy of multiple genes" (Gupta \& State, 2007) - that converge leading to a given phenotype.

Despite the indirect evidence for heritability and recent genetic technological advances, a genetic cause can be attributed to only $10-20 \%$ of all cases (reviewed in Abrahams \& Geschwind, 2008), with a recent report suggesting a genetic cause can be uncovered in up to $40 \%$ of cases (Schaefer \& Lutz, 2006). Further, Abraham and Geschwind (2008) state that no single genetic cause accounts for more than $1-2 \%$ of cases - similar to what is seen in mental retardation, another condition without a single genetic cause. While numerous studies identifying candidate genes 
or makers have been reported, very few studies have been replicated (Losh et al., 2008). Reasons to explain why candidates have not been agreed upon include the initial lack of uniform diagnostic criteria (strict vs. broad definition), limited power, varying methodology (Losh et al., 2008), and neglect of epigenetic factors modeling the disorder (Lahiri, Maloney, \& Zawia, 2009). Further, as with other conditions with a strong heritable component, it appears that different genes may contribute to distinct components of the condition which gives rise to the full disorder through concerted actions (Losh et al., 2008; Pickles et al., 1995). Consequently, it has been said that linkage technology has not "found the autism gene," but rather it demonstrated that more powerful technology is necessary to explain the multiple genes associated with autism (Abrahams \& Geschwind, 2008). No one knows just how heterogeneous the syndrome is likely to be, that is, how many genes or regions of DNA (loci) may contribute either within a single individual or among the entire group of affected individuals. Some of the chromosomal regions and genes that have been associated with autism are summarized in Table 6.1 and will be addressed herein.

In addition, it is important to distinguish between locus heterogeneity, which refers to a variation at many different genes or loci resulting in a similar phenotype, and allelic heterogeneity, which refers to different variations or mutations at the same locus leading to an identical or overlapping clinical picture. Accumulating evidence suggest that both play a role in autism (O'Roak \& State, 2008).

Recently, a rare-variant common disease model has been introduced (O'Roak \& State, 2008). In this model, rare genes explain the common disease of autism. This makes sense in the Darwinian tradition that a deleterious change

Table 6.1 The polygenetics of autism, selected chromosomal regions, and genes

\begin{tabular}{|c|c|c|c|c|c|}
\hline $\begin{array}{l}\text { Chromosome } \\
\text { and location }\end{array}$ & $\begin{array}{l}\text { Specific gene } \\
\text { (if applicable) }\end{array}$ & $\begin{array}{l}\text { Gene name } \\
\text { (if applicable) }\end{array}$ & $\begin{array}{l}\text { Normal protein function } \\
\text { (if applicable) }\end{array}$ & $\begin{array}{l}\text { Autism-associated } \\
\text { endophenotypes } \\
\text { (if applicable) }\end{array}$ & References \\
\hline $2 \mathrm{p} 16.3$ & $N R X N 1$ & Neurexin 1 & $\begin{array}{l}\text { Cell adhesion, receptor, } \\
\text { nervous system }\end{array}$ & & $\begin{array}{l}\text { Lintas and Persico } \\
\text { (2009), Etherton } \\
\text { et al. (2009); } \\
\text { Szatmari et al. } \\
\text { (2007) }\end{array}$ \\
\hline $2 q$ & & & & & $\begin{array}{l}\text { IMGSAC (1998), } \\
\text { (2001b) }\end{array}$ \\
\hline $2 q 37$ & & & & & $\begin{array}{l}\text { Costa de Silva } \\
\text { (2008); Schaefer and } \\
\text { Mendelsohn (2008) }\end{array}$ \\
\hline $5 \mathrm{p} 15$ & & & & & Weiss et al., 2009 \\
\hline $5 \mathrm{p} 15.2$ & SEMA5A & $\begin{array}{l}\text { Sema domain, seven } \\
\text { thrombospondin repeats } \\
\text { (type } 1 \text { and type } 1 \text {-like), } \\
\text { transmembrane domain } \\
\text { (TM), and short } \\
\text { cytoplasmic domain } \\
\text { (semaphorin) 5A }\end{array}$ & $\begin{array}{l}\text { Involved in axonal } \\
\text { guidance during neural } \\
\text { development }\end{array}$ & & Weiss et al. (2009) \\
\hline
\end{tabular}

\begin{tabular}{|c|c|c|c|c|c|}
\hline $6 q 27$ & & & & & Weiss et al. (2009) \\
\hline $7 q$ & & & & $\begin{array}{l}\text { Specific language } \\
\text { impairment }\end{array}$ & Losh et al. (2008) \\
\hline $7 q 21-22$ & & & & & $\begin{array}{l}\text { IMGSAC (1998), } \\
\text { (2001a) }\end{array}$ \\
\hline $7 \mathrm{q} 22$ & $R E L N$ & Reelin & $\begin{array}{l}\text { Controls cell-cell } \\
\text { interactions critical for } \\
\text { cell positioning and } \\
\text { neuronal migration } \\
\text { during brain } \\
\text { development }\end{array}$ & & $\begin{array}{l}\text { Ashley et al. (2007); } \\
\text { Persico et al. (2002); } \\
\text { Zhang et al. (2002) }\end{array}$ \\
\hline $7 \mathrm{q} 31$ & FOXP2 & Forkhead box P2 & $\begin{array}{l}\text { Development of speech } \\
\text { and language regions of } \\
\text { the brain during } \\
\text { embryogenesis }\end{array}$ & $\begin{array}{l}\text { Specific language } \\
\text { impairment }\end{array}$ & $\begin{array}{l}\text { Konopka et al. } \\
\text { (2009); Lai et al. } \\
\text { (2001); O'Brien } \\
\text { et al. (2003) }\end{array}$ \\
\hline
\end{tabular}


Table 6.1 (continued)

\begin{tabular}{|c|c|c|c|c|c|}
\hline $\begin{array}{l}\text { Chromosome } \\
\text { and location }\end{array}$ & $\begin{array}{l}\text { Specific gene } \\
\text { (if applicable) }\end{array}$ & $\begin{array}{l}\text { Gene name } \\
\text { (if applicable) }\end{array}$ & $\begin{array}{l}\text { Normal protein function } \\
\text { (if applicable) }\end{array}$ & $\begin{array}{l}\text { Autism-associated } \\
\text { endophenotypes } \\
\text { (if applicable) }\end{array}$ & References \\
\hline $7 \mathrm{q} 31.1-31.3$ & $S T 7$ & $\begin{array}{l}\text { Suppression of } \\
\text { tumorigenicity } 7\end{array}$ & Function not determined & & Vincent et al., 2002 \\
\hline $7 \mathrm{q} 31.2$ & $W N T 2$ & $\begin{array}{l}\text { Wingless-type MMTV } \\
\text { integration site family } \\
\text { member } 2\end{array}$ & $\begin{array}{l}\text { Implicated in } \\
\text { oncogenesis and in } \\
\text { several developmental } \\
\text { processes }\end{array}$ & & $\begin{array}{l}\text { Wassink et al. (2004) } \\
\text { Lai et al. (2001) }\end{array}$ \\
\hline $7 q 32-36$ & & & & & $\begin{array}{l}\text { IMGSAC (1998); } \\
\text { CLSA (1999) }\end{array}$ \\
\hline $7 q 35-36$ & CNTNAP2 & $\begin{array}{l}\text { Contactin-associated } \\
\text { protein-like } 2\end{array}$ & $\begin{array}{l}\text { Cell adhesion, local } \\
\text { axonal differentiation }\end{array}$ & $\begin{array}{l}\text { Autism language } \\
\text { phenotype }\end{array}$ & $\begin{array}{l}\text { Strauss et al. (2006), } \\
\text { Jackman et al. } \\
\text { (2009), Alarcon } \\
\text { et al. (2008) }\end{array}$ \\
\hline $9 q 34$ & TSC1 & Tuberous sclerosis 1 & $\begin{array}{l}\text { Growth inhibitory } \\
\text { protein }\end{array}$ & & $\begin{array}{l}\text { Au et al. (2004); } \\
\text { Fryer et al. (1987) }\end{array}$ \\
\hline $10 \mathrm{q} 23.3$ & PTEN & $\begin{array}{l}\text { Phosphatase and tensin } \\
\text { homolog }\end{array}$ & $\begin{array}{l}\text { Tumor suppressor, } \\
\text { negatively regulates } \\
\text { AKT/PKB signaling }\end{array}$ & Macrocephaly & $\begin{array}{l}\text { Kwon et al. (2006); } \\
\text { Butler et al. (2005), } \\
\text { Herman et al. } \\
\text { (2007a) }\end{array}$ \\
\hline $11 q 12-p 13$ & & & & & $\begin{array}{l}\text { Szatmari et al. } \\
\text { (2007) }\end{array}$ \\
\hline $11 q 13$ & $N R X N 2$ & Neurexin 2 & $\begin{array}{l}\text { Cell adhesion, receptor, } \\
\text { nervous system }\end{array}$ & & $\begin{array}{l}\text { Lintas and Persico } \\
\text { (2009) }\end{array}$ \\
\hline $13 q 21$ & & & & $\begin{array}{l}\text { Specific language } \\
\text { impairment }\end{array}$ & $\begin{array}{l}\text { Bartlett et al. (2002), } \\
\text { (2004) }\end{array}$ \\
\hline $14 \mathrm{q} 31$ & $N R X N 3$ & Neurexin 3 & $\begin{array}{l}\text { Cell adhesion, receptor, } \\
\text { nervous system }\end{array}$ & & Feng et al. (2006) \\
\hline $15 q 11-13$ & & & & $\begin{array}{l}\text { Mental retardation, } \\
\text { motor impairment, } \\
\text { seizure, impairment } \\
\text { in communication, } \\
\text { restrictive and } \\
\text { repetitive behavior }\end{array}$ & $\begin{array}{l}\text { Cook et al. (1997); } \\
\text { Schroer et al. (1998); } \\
\text { Shao et al. (2003) }\end{array}$ \\
\hline
\end{tabular}

\begin{tabular}{|c|c|c|c|c|c|}
\hline $16 \mathrm{p} 13.3$ & $T S C 2$ & Tuberous sclerosis 2 & $\begin{array}{l}\text { Tumor suppressor, } \\
\text { stimulates specific } \\
\text { GTPases }\end{array}$ & & Au et al. (2004) \\
\hline $16 \mathrm{q} 24$ & & & & $\begin{array}{l}\text { Specific language } \\
\text { impairment }\end{array}$ & $\begin{array}{l}\text { SLI Consortium } \\
\text { (2002), (2004) }\end{array}$ \\
\hline $17 \mathrm{p} 11$ & & & & & $\begin{array}{l}\text { Costa e Silva (2008); } \\
\text { Schaefer and } \\
\text { Mendelsohn (2008) }\end{array}$ \\
\hline $17 q 11-17$ & & & & & Cantor et al. (2005) \\
\hline $17 q 11.1-q 12$ & SLC6A4 & $\begin{array}{l}\text { Solute carrier family } 6 \\
\text { (neurotransmitter } \\
\text { transporter, serotonin), } \\
\text { member } 4\end{array}$ & $\begin{array}{l}\text { Transports serotonin } \\
\text { into presynaptic neurons }\end{array}$ & & Losh et al. (2008) \\
\hline $18 \mathrm{q} 21.2-22.3$ & & & & & Mahr et al. (1996) \\
\hline $19 \mathrm{q} 13$ & & & & $\begin{array}{l}\text { Specific language } \\
\text { impairment }\end{array}$ & $\begin{array}{l}\text { SLI Consortium } \\
(2002),(2004)\end{array}$ \\
\hline 20 p13 & & & & & Weiss et al. (2009) \\
\hline $21 \mathrm{q} 21.2-21.3$ & $A P P$ & $\begin{array}{l}\text { Amyloid beta (A4) } \\
\text { precursor protein }\end{array}$ & $\begin{array}{l}\text { Neurite outgrowth, cell } \\
\text { adhesion }\end{array}$ & $\begin{array}{l}\text { Self-injurious and } \\
\text { aggressive behavior }\end{array}$ & $\begin{array}{l}\text { Bailey et al. (2008); } \\
\text { Sokol et al. (2006) }\end{array}$ \\
\hline
\end{tabular}


Table 6.1 (continued)

\begin{tabular}{|c|c|c|c|c|c|}
\hline $\begin{array}{l}\text { Chromosome } \\
\text { and location }\end{array}$ & $\begin{array}{l}\text { Specific gene } \\
\text { (if applicable) }\end{array}$ & $\begin{array}{l}\text { Gene name } \\
\text { (if applicable) }\end{array}$ & $\begin{array}{l}\text { Normal protein function } \\
\text { (if applicable) }\end{array}$ & $\begin{array}{l}\text { Autism-associated } \\
\text { endophenotypes } \\
\text { (if applicable) }\end{array}$ & References \\
\hline $22 q 11$ & & & & & $\begin{array}{l}\text { Costa e Silva (2008); } \\
\text { Schaefer and } \\
\text { Mendelsohn (2008); } \\
\text { Sykes and Lamb } \\
\text { (2007) }\end{array}$ \\
\hline $22 q 13$ & & & & & $\begin{array}{l}\text { Costa e Silva (2008); } \\
\text { Schaefer and } \\
\text { Mendelsohn (2008); } \\
\text { Sykes and Lamb } \\
(2007)\end{array}$ \\
\hline $22 \mathrm{q} 13.3$ & SHANK3 & $\begin{array}{l}\text { SH3 and multiple } \\
\text { ankyrin repeat } \\
\text { domains } 3\end{array}$ & $\begin{array}{l}\text { Connects } \\
\text { neurotransmitter } \\
\text { receptors, ion channels, } \\
\text { and other membrane } \\
\text { proteins to the actin } \\
\text { cytoskeleton and } \mathrm{G} \\
\text { protein-coupled } \\
\text { signaling pathways, and } \\
\text { plays a role in synapse } \\
\text { formation and dendritic } \\
\text { spine maturation }\end{array}$ & & $\begin{array}{l}\text { Durand et al. (2007); } \\
\text { Moessner et al. } \\
\text { (2007) }\end{array}$ \\
\hline Xp & & & & & $\begin{array}{l}\text { Schaefer and } \\
\text { Mendelsohn (2008) }\end{array}$ \\
\hline $\mathrm{Xq13.1}$ & NLGN3 & Neuroligin 3 & $\begin{array}{l}\text { Formation and } \\
\text { remodeling of central } \\
\text { nervous system } \\
\text { synapses }\end{array}$ & & Jamain et al. (2003) \\
\hline $\mathrm{Xq} 22.31-32$ & $N L G N 4 X$ & Neuroligin 4, X-linked & $\begin{array}{l}\text { Formation and } \\
\text { remodeling of central } \\
\text { nervous system } \\
\text { synapses }\end{array}$ & & $\begin{array}{l}\text { Jamain et al. (2003), } \\
\text { Laumonnier et al. } \\
\text { (2004); } \\
\text { Lawson-Yuen et al. } \\
\text { (2008) }\end{array}$ \\
\hline $\mathrm{Xq} 27.3$ & $F M R 1$ & $\begin{array}{l}\text { Fragile } X \text { mental } \\
\text { retardation } 1\end{array}$ & $\begin{array}{l}\text { mRNA translation } \\
\text { regulation }\end{array}$ & $\begin{array}{l}\text { Gaze avoidance, } \\
\text { stereotypic movements, } \\
\text { echolalia, ritualistic } \\
\text { behaviors }\end{array}$ & $\begin{array}{l}\text { Einfeld et al. (1989); } \\
\text { Maes et al. (1993) }\end{array}$ \\
\hline $\mathrm{Xq} 28$ & $M E C P 2$ & $\begin{array}{l}\text { Methyl-CpG-binding } \\
\text { protein } 2\end{array}$ & $\begin{array}{l}\text { Binds to methyl-CpG in } \\
\text { methylation regulation } \\
\text { of gene expression }\end{array}$ & $\begin{array}{l}\text { Mental retardation, } \\
\text { female only }\end{array}$ & $\begin{array}{l}\text { Lintas and Persico } \\
\text { (2009) }\end{array}$ \\
\hline $\mathrm{XY}$ mosaicism & & & & & $\begin{array}{l}\text { Costa e Silva (2008); } \\
\text { Sykes and Lamb } \\
\text { (2007); Schafer and } \\
\text { Mendelsohn (2008) }\end{array}$ \\
\hline $\mathrm{XYY}$ & & & & & $\begin{array}{l}\text { Costa e Silva (2008); } \\
\text { Schaefer and } \\
\text { Mendelsohn (2008) }\end{array}$ \\
\hline
\end{tabular}

${ }^{\mathrm{a} C h r o m o s o m e ~ l o c a t i o n, ~ g e n e ~ s y m b o l, ~ g e n e ~ n a m e, ~ a n d ~ p r o t e i n ~ f u n c t i o n ~ a r e ~ f r o m ~ t h e ~ N C B I ~ E n t r e z ~ g e n e ~ d a t a b a s e ~(h t t p: / / w w w . n c b i . n l m . n i h . g o v / ~}$ gene/), accessed 1 January 2010

in the human genome leads to reduced fitness and that this would not be likely to propagate within a population. Autism fits the rare gene-common disease model as it begins early in life, impairs social interactions, and is associated with mental retardation which impacts reproductive fitness (O'Roak \& State, 2008). The large difference seen between monozygotic and dizygotic concordance rates is consistent with de novo (rare gene) mutation. It appears that simplex families demonstrate de novo mutations more frequently with one family member with autism (Sebat et al., 2007) whereas multiplex families demonstrate transmitted variants (Bakkaloglu et al., 2008). The search for rare variants has 
led to the study of families that are genetically isolated, with shared ancestry and prone to consanguinity (Morrow et al., 2008; Strauss et al., 2006) to locate recessive alleles. Finally, rare sequence variations have been detected, thanks to improved technology such as CNV analysis. Indeed within the last 5-10 years, 20 bona fide risk genes have been identified due to the improved technology developed after the linkage method (Abrahams \& Geschwind, 2008). Several of these risk genes will be discussed in the following sections.

\section{Genetic Research}

Abrahams and Geschwind (2008) write that two views underlie genetic autism research. The first is that rare variants involve an abnormality in a single molecule causing the clinical pathology in autism. Mendelian inheritance (autosomal dominant vs. recessive) takes this form. Technology compatible with this approach includes cytogenetics (including karyotyping and FISH), gene association studies (analysis of genes and protein system from less complex genetic syndromes similar to autism such as Rett and fragile $\mathrm{X}$ syndromes), linkage studies (including genome screens in affected sibling pairs), microarray technology, and CNV analysis. The second view involves the study of independent hereditary endophenotypes representing the core features of autism. An endophenotype is an operationally defined behavioral feature such as age of first spoken word. Although there is a general consensus regarding endophenotypes commonly seen in autism, the behaviors may not be specific to autism, as delay in language acquisition accompanies many developmental disorders. Ideally, endophenotypes represent discreet behaviors which do not overlap with other behaviors from the autism core domains (i.e., language, socialization, and rigid behavior). For example, poor eye contact, representing a deficit with socialization, is construed as being independent of repetitive behaviors, thought to represent the rigid behavior domain. Genetic study of these discreet endophenotypes, largely undertaken via linkage studies, narrows the scope of analysis (Losh et al., 2008; O'Roak \& State, 2008).

\section{Cytogenetics: Rare Mutations}

Reports of chromosomal abnormalities detected by karyotyping first demonstrated that rare variants may contribute to autism (Vorstman et al., 2006). Estimates of chromosomal abnormalities in autism range from 6 to $40 \%$ (Abrahams \& Geschwind, 2008; Marshall et al., 2008; Pennington, 2009; Schaefer \& Lutz, 2006) so that genetic workup is now being recommended for all children diagnosed with autism (Pennington, 2009; Schaefer \& Mendelsohn, 2008).

\section{Chromosome 15q11-13}

Chromosomal studies have produced a great interest in chromosome 15q11-13, the site of the most frequent chromosomal anomaly seen in autism (reviewed in VeenstraVanderWeele \& Cook, 2004). The maternally derived duplication of this region involves an imprinting mechanism. Maternal interstitial duplication or supernumerary inverted duplication of $15 q 11-13$ is seen in $1-3 \%$ of patients (Cook et al., 1990; Schroer et al., 1998). Clinical features of chromosomal derangement in this region include mental retardation, motor impairment, seizure disorder, and impairment in communication, in some but not all with autism or attentiondeficit hyperactivity disorder (ADHD; Cook et al., 1997; Schroer et al., 1998).

The duplication of 15q11-13 seen in some cases of autism is the opposite of deletions from the same region seen in Angelman's syndrome (if inherited from the mother) or Prader Willi syndrome (if inherited from the father). Angelman's syndrome, known as the "happy puppet" phenotype, involves mental retardation, epilepsy, ataxia, lack of speech, predominant laughing and smiling, and a high rate of autism. Prader Willi syndrome associated with mental retardation and hyperphagia is only occasionally associated with autism. Presently, there is ongoing research regarding how duplications and deletions in this gene region lead to an increased risk of autism (Veenstra-VanderWeele \& Cook, 2004). This region, however, has not been identified as one of interest in whole genome searches, perhaps due to its rarity (Pennington, 2009). Still, FISH analysis of chromosome 15q11-13 is often performed in evaluation of children with autism. Recently, FISH is being replaced by CGH due to improved detection of abnormality within the 15q11-13 region.

\section{Fragile X Syndrome}

Cytogenetic approaches provided the first evidence for an autism gene 40 years ago when Lubs (1969) identified an abnormal or "fragile" site on the long arm of chromosome X in four males with mental retardation, leading to the recognition of fragile X syndrome (FXS). This syndrome, associated with mental retardation and autistic features, is more severely expressed in males. FXS is caused by a deficiency of the fragile $\mathrm{X}$ mental retardation protein (FMRP), resulting from little or none of the disease gene fragile $\mathrm{X}$ mental retardation 1 (FMR1) mRNA. The FMR1 gene mutation consisting of expanded CGG repeats of $>200$ at chromosome site Xq27.3 is considered the origin of FXS. Autism, using the broad definition, has been reported in up to $30 \%$ of males with FXS, and FXS can be found in as many as 7-8\% of individuals with autism (Muhle, Trentacoste, \& Rapin, 2004). 
Later studies, using DNA measures of the fragile X mutation rather than cytogenetics and strict autism criteria, have found a smaller association between FXS and autism (Pennington, 2009). Two investigations, however, which studied carefully controlled groups of FXS-negative and FXS-positive males matched on intelligence, found higher rates of the following autistic symptoms in FXS males: gaze avoidance and hand flapping (Einfeld, Molony, \& Hall, 1989) and stereotypic movements (including hand flapping, rocking, and hitting, scratching, or rubbing their own bodies), echolalia, gaze avoidance, and ritualistic behaviors (Maes, Fryns, Van Walleghem, \& Van den Berghe, 1993). Studies of endophenotype behaviors rather than the strict autism criteria are more likely to uncover robust similarities between FXS and autism.

Exploring similarities between rare sub-groups of patients with a known disorder and those with a more common disorder (autism) provides a window into the shared biology between the disorders. FMRP has been shown to interact with multiple transcripts in repressing metabotropic glutamate receptor-5 $\left(\mathrm{mGluR}_{5}\right)$ signaling activity which regulates long-term depression (LTD) associated with synaptic elimination. Without FMRP acting as a "brake," mGluR-LTD is enhanced (Bear, Huber, \& Warren, 2004). This favors an anabolic state which could contribute to the key features of FXS such as epilepsy, cognitive impairment, loss of motor coordination, and increased density of thin, long, dendritic spines in neurons (Bear, 2005). These observations have invited drug trials of glutamate receptor antagonists to reduce the expression of $\mathrm{mGluR}_{5}$ (Dolen et al., 2007) in individuals with FXS and in individuals with autism.

\section{Investigation of Candidate Genes Contributing to Biochemical Pathways}

Other genes contributing to medical conditions such as Alzheimer's disease are under investigation to determine if they, too, share biology with autism and FXS. The discovery of fragile $\mathrm{X}$ ataxia syndrome (FXTAS) provides a precedent to study the relationship of developmental conditions across the life span within and between families. FXTAS is an adult-onset ataxia/dementia syndrome found in older family members of individuals with FXS (Hagerman, 2002; Hagerman et al., 2001). In contrast to what is found in FXS, FXTAS occurs with a rise in FMRl mRNA level (Hagerman, 2006), fewer than 200 repeats (Basehore \& Friez, 2009), and hypomethylation (Berry-Kravis, Potanas, Weinberg, Zhou, \& Goetz, 2005) in the FMR1 CGG section on the X chromosome. This association of two clinically divergent disorders, regulated by the same gene produced in different doses, sets the stage for the investigation of the shared biology between autism, FXS, and other genes related to Alzheimer's disease such as amyloid precursor protein (APP).

\section{Amyloid Precursor Protein}

APP, which is encoded by a gene on chromosome 21 , is a large (695-770 amino acid) glycoprotein produced in several central nervous system (CNS) cell types including microglia, astrocytes, oligodendrocytes, and neurons. After protein processing, mature APP is axonally transported and can be released from axon terminals in response to electrical activity. APP is believed to play an important role in neuronal maturation and in synaptogenesis as reviewed by Lahiri, Farlow, Greig, Giacobini, and Schneider (2003). APP is of great interest because processing products of APP can include the insoluble 40-42-amino acid amyloid $\beta$-peptide ( $A \beta-40$ and $A \beta-42$, respectively), the principal component of the cerebral plaques associated with memory and cognitive decline in Alzheimer's disease (Alley et al., 2010). Recent research linking APP to autism illustrates how association studies enable the generation of new hypotheses about the biology of autism and ultimately advance our understanding of this disorder. Recently, we found evidence to support an association between autism and one of the APP pathways established for Alzheimer's disease. In contrast to the upregulation of the amyloidogenic pathway as seen in Alzheimer's disease, we found evidence that there may be an upregulation of the nonamyloidogenic ( $\alpha$-secretase amyloid precursor protein, $\mathrm{sAPP} \alpha$ ) pathway in a small sample of children with severe autism associated with self-injurious and aggressive behavior. That is, children with severe autism expressed total sAPP (representing the combined amyloidogenic and nonamyloidogenic pathways) at two or more times the levels of children without autism and up to four times the levels of children with mild autism (Sokol et al., 2006). Overall, there was a trend toward higher $\operatorname{sAPP} \alpha$ within the children with autism. One of the severely autistic children in this study had FXS. High levels of sAPP $\alpha$ have also been found in a sample of children with autism from an independent laboratory (Bailey et al., 2008). High levels of sAPP $\alpha$ imply an increased $\alpha$-secretase pathway in autism (anabolic), opposite to what is seen in Alzheimer's disease. This would be consistent with the brain overgrowth hypothesis attributed to autism, in contrast to the brain atrophy seen with the deposition of amyloid plaque in Alzheimer's disease. Coincidentally, via animal studies, Westmark and Malter (2007) concluded that FMRP binds to and regulates translation of APP mRNA through $\mathrm{mGLuR}_{5}$, providing a potential link between neuronal proteins associated with AD and FXS. By way of GluR $_{5}$, FMRP provides the "brake," which if unchecked in conditions such as FXS would favor high levels of APP. Further, high levels of APP have been 
found in another study of FMR1 knockout mice (D'Agata et al., 2002). These findings have led to enticing speculation that the APP gene may influence several neurodevelopmental disorders across the life span.

\section{Chromosome 7q}

Both chromosomal inversions and translocations have been reported near 7q31 in boys with autism. One of these translocation breakpoints identified the deranged gene as RAY1/ST7 (FAM4A1), a putative tumor suppressor gene (Vincent et al., 2002), and work in this region is ongoing. Mutations leading to amino acid changes have been found on the WNT2 gene on 7q31 in two families with autism, and one affected parent transmitting the mutation to two affected children (Li et al., 2004; Wassink, Brzustowicz, Bartlett, \& Szatmari, 2004). The FOXP2 gene on 7q31 was found to be disrupted in one family with an autosomal dominant form of specific language impairment (SLI) (Lai, Fisher, Hurst, Vargha-Khadem, \& Monaco, 2001), and this was replicated in a larger study of SLI (O'Brien, Zhang, Nishimura, Tomblin, \& Murray, 2003), although initial studies failed to associate this with autism (Newbury et al., 2002; Wassink et al., 2001). Recently, FOXP2 differences in gene expression were found between chimp and human cell cultures (Konopka et al., 2009). Compared to chimps, in human culture, the FOXP2 gene affected transcription upregulation in 61 genes and downregulation in 55 genes. Further, the FOXP2 gene was shown to regulate downstream effects involving cerebellar motor function, craniofacial formation, and cartilage and connective tissue formation required for expressive language. As discussed in section "Endophenotype," there is a suspected association between the chromosome 7q region and speech abnormality seen in autism.

The RELN gene maps to chromosome 7q22. This gene encodes a protein that controls intercellular interactions involved in neuronal migration and positioning in brain development. A large polymorphic trinucleotide repeat in the $5^{\prime}$-YTR of the RELN gene has been implicated in autism in several studies (Ashley-Koch et al., 2007; Persico et al., 2002; Zhang et al., 2002). Further support for this candidate gene comes from the RELN mouse model which carries a large deletion in RELN and shows atypical cortical organization similar to cytoarchitectural pathological anomalies reported in the brains of individuals with autism (Bailey et al., 2008).

\section{Phosphatase and Tensin Homolog Gene (PTEN)}

PTEN is a tumor suppressor gene located on chromosome 10q23. This gene influences the cell-cell arrest cycle and apoptosis or programmed cell death (Lintas \& Persico, 2009). PTEN inactivation causes excessive growth of dendrites and axons, with an increased number of synapses (Kwon et al., 2006). Mutations in PTEN cause Cowden's syndrome (macrocephaly, hamartomas, and autism). This gene has been of interest to autism researchers as macrocephaly has been considered to be one of the "most widely replicated biological findings in autism" affecting up to $20 \%$ of all children with the condition (McCaffery \& Deutsch, 2005). Butler et al. (2005) examined the PTEN gene in 18 individuals with autism and macrocephaly. They discovered three with PTEN missense mutations. Others have found PTEN mutations in macrocephalic patients with autism (Herman et al., 2007a, 2007b).

\section{Other Cytogenetic Regions}

Cytogenic abnormalities have included deletions and duplications involving 2q37, 22 q13, 22q11, 17p11, 16p11.2,18q, $\mathrm{Xp}$, and sex chromosome aneuploidies (47, XYY and 45, X/46, and XY mosaicism) (Costa e Silva, 2008; Mendelsohn \& Schaefer, 2008; Schaefer \& Mendelsohn, 2008; Sykes \& Lamb, 2007). These genetic findings have generated interest in testing the association of a number of candidate genes in these regions via linkage and animal studies.

\section{Autism and Synapse Formation (Synaptogenesis) Overview}

Accumulating evidence points to the involvement of three genes (neuroligin, SHANK3, and neurexin) in the synapse formation of glutamate neurons. Glutamate is an excitatory neurotransmitter and aberrant glutamate function has long been suspected to contribute to autism. Neuroligins induce presynaptic differentiation in glutamate axons. SHANK3 encodes for a postsynaptic scaffolding protein which regulates the structural organization of dendritic spines in neurons. Consequently, SHANK3 is a binding partner of neuroligins. Neurexin induces glutamate postsynaptic differentiation in contacting dendrites. Altogether, these genes appear to contribute to glutamatergic synapse formation.

\section{Neuroligin Genes (NLGN3 and NLGN4)}

Neuronal cell adhesion is important in the development of the nervous system, contributing to axonal guidance, synaptic formation and plasticity, and neuronalglial interactions (Glessner et al., 2009; Lien, Klezovitch, \& Vasioukhin, 2006). Derangement in cell adhesion could contribute to migrational abnormalities including brain overgrowth. Neuroligins are cell-adhesion molecules 
localized postsynaptically at both glutamatergic (NLGN1, NLGN3, NLGN4, NLGN4Y) and $\gamma$-aminobutyric acidergic (NLGN2) synapses (Lintas \& Persico, 2009). Neuroligins trigger the formation of functional presynaptic structures in contacting axons. As mentioned above, they interact with postsynaptic scaffolding proteins such as SHANK3 (see below). The $N L G N 3$ and NLGN4 genes are located at chromosomes Xq13 and Xq22, 33, respectively, and mutations here have been associated with autism Jamain et al. (2003). Extensive genetic screens conducted by several research groups have confirmed the low frequency of neuroligin mutations among individuals with autism (Lintas \& Persico, 2009). For example, Jamain et al. (2003) found a frameshift mutation in NLGN4 and a missense mutation in NLGN3 in two unrelated Swedish families, inherited from unaffected mothers. Laumonnier et al. (2004) reported a frameshift mutation in NLGN4 in 13 affected male members of a single pedigree. Lawson-Yuen, Saldivar, Sommer, and Picker (2008) found a deletion of exons 4-6 of NLGN4 in a boy with autism and in his brother with Tourette syndrome whose mother showed psychiatric problems and also carried the mutation. Neuroligin mutation carriers, however, display a variety of syndromes, such as X-linked mental retardation without autism (Laumonnier et al., 2004), Asperger's syndrome, autistic disorder of variable severity, and PDD-NOS (Yan et al., 2005). The symptoms may be slow, or abrupt and associated with regression. Despite intensive investigation, the low frequency of neuroligin mutations and the lack of similar phenotypes have led to the recommendation that neuroligins should not be included in widespread screens for individuals with nonsyndromic autism (Lintas \& Persico, 2009).

\section{SH3 Multiple Ankyrin Repeat Domains 3 Gene (SHANK3)}

The SHANK3 gene is located on chromosome 22q13.3 which encodes for a scaffolding protein found in the postsynaptic density complex of excitatory synapses binding to neuroligins. Recently, two studies have reported a correlation between mutations affecting SHANK3 and an autism phenotype characterized by severe verbal and social deficits (Durand et al., 2007; Moessner et al., 2007). Of the seven patients reported with the SHANK3 gene mutations, five were deletions, one was a missense, and another a frameshift mutation. In addition, rare SHANK3 variations were present in the autism group, but not in the control group. These variations were inherited from healthy parents and they were present in unaffected siblings, perhaps demonstrating incomplete penetrance. Another interesting observation is that in both studies (Durand et al., 2007; Moessner et al., 2007), the SHANK3 deletion was inherited via a paternal balanced translocation. Further, in both studies, siblings of the probands with SHANK3 abnormalities had partial 22q13 trisomy that resulted in attention-deficit hyperactivity disorder (Moessner et al., 2007) and Asperger's syndrome with early language development (Durand et al., 2007). Like neuroligins, SHANK3 mutations are very rare. However, because of the robust genotype-phenotype correlation reported in two studies (Durand et al., 2007; Moessner et al., 2007), it has been recommended that children with severe language and social impairment obtain SHANK3 mutation screening (Lintas \& Persico, 2009).

\section{Neurexin Genes}

Presynaptic neurexins influence postsynaptic differentiation in contacting dendrites by interactions with postsynaptic neuroligins. Three neurexin genes (NRXN1, NRXN2, and $N R X N 3)$ are located on chromosome loci $2 \mathrm{q} 32,11 \mathrm{q} 13$, and 14q24.3-q31.1, respectively. Again, neurexin mutations are very rare. For example, two missense mutations were present in 4 of $264(1.5 \%)$ individuals with autism compared to none in 729 controls (Feng et al., 2006). However, in this study, missense mutations also occurred in first-degree relatives who displayed heterogeneous phenotypes such as hyperactivity, depression, and learning problems. Incomplete penetrance may explain these findings, or autism may be caused by neurexin acting synergistically with other susceptibility genes. Neurexin- $1 \alpha$ is being intensely studied in mice as deletion in this molecule resulted in increased repetitive behavior, whereas social behavior was relatively intact (Etherton, Blaiss, Powell, \& Sudhof, 2009). This implies an animal model for a discreet feature of autistic behavior (endotype), as discussed below.

Contactin-associated protein-like 2 (CNTNAP2) is a member of the neurexin superfamily which involves a recessive frameshift mutation on chromosome $7 \mathrm{q} 35$. It is one of the largest genes of the human genome and encodes CASPR2, a transmembrane scaffolding protein. CNTNAP2 has been associated with cortical dysplasia-focal epilepsy in an Old Order Amish community (Strauss et al., 2006). Autism was present in up to $67 \%$ of these individuals. We recently reported CNTNAP2 in an Amish girl with epilepsy and autism who also showed hepatosplenomegaly (Jackman, Horn, Molleston, \& Sokol, 2009). CNTNAP2 has been associated with an autism language phenotype in large studies of non-Amish individuals (Alarcon et al., 2008). Further, stage two of this investigation showed that CNTNAP2 was expressed in the language centers (frontal and anterior temporal lobes) of fetal brain (Alarcon et al., 2008). It has been recommended that Amish children presenting with autism should be tested for CNTNAP2 gene mutation (Strauss, 
personal communication). This work again supports a language function associated with chromosome 7 .

\section{The Methyl-CpG-Binding Protein 2 Gene}

Methyl-CpG-binding protein 2 (MeCP2) works as a transcriptional repressor within gene-promoting regions involved in chromatin repression. This gene is located on chromosome Xq28 and shows mutation in $80 \%$ of females with Rett syndrome (pervasive developmental disorder, acquired microcephaly, epilepsy, and loss of hand function). This gene has been studied in children with autism, and $\mathrm{MeCP} 2$ mutations are considered to be rare $(0.8-1.3 \%)$ in females with autism. Interestingly, autism and Rett syndrome share some similarities at the phenotypic and pathogenic levels, and both disorders were proposed to result from disruption of postnatal or experience-dependent synaptic plasticity (Zoghbi, 2003). Among the Rett mutations reported are a frameshift mutation, a nonsense mutation, and additional introns (Lintas \& Persico, 2009). Schaefer and Mendelsohn (2008) observe that MeCP2 has not been associated with idiopathic autism in males so that this gene test is recommended only for females with autism.

\section{Linkage Studies}

Linkage studies involve determining whether the transmission of a chromosomal segment from one generation to another coincides with the presence of the phenotype of interest (Gupta \& State, 2007). Linkage can be utilized in Mendelian inherited conditions and can also be used to study complex conditions such as in autism when Mendelian inheritance is unlikely, and there is no hypotheses regarding the specific nature of transmission.

Linkage studies can be grouped into two types - the conventional study of a chromosomal region of interest in affected sibling-pairs from multiplex families and the more recent genome-wide linkage analysis in which every chromosome is evaluated simultaneously. In the sib-pair study method, siblings with autism are evaluated to determine whether they share any regions of the genome more frequently than would be expected by chance.

Genomic wide association studies compare genetic risk factors in the form of specific genetic markers in cases and controls. These markers are distributed within the entire genome rather than limited to specific gene regions such as in the sib-pair method. This enables a more unbiased ascertainment of regions of interest (Losh et al., 2008). Several genome-wide scans of individuals with autism have been reported and evidence in favor of linkage has been determined for the majority of chromosomes (Gupta \& State,
2007). The trouble with these studies is that the evidence has not reached statistical significance and there is lack of replication for many of these findings. Statistical significance is calculated by a logarithm of the odds (LOD) score. This score represents the logarithm of the likelihood ratio of observing the data under a model of linkage to observing the data under a model of free recombination (no linkage). An LOD score of 3.5 in a sib-pair analysis is considered to be a significant linkage (Lander \& Kruglyak, 1995). Suggestive linkage is an LOD score of 2.2, and a highly significant LOD score is 5.4. For replication studies, the replication threshold is considered to be 1.4 (Lander \& Kruglyak, 1995). By chance, one would expect to see a suggestive linkage peak once every genome scan or a significant peak once every 20 scans (Gupta \& State, 2007).

Most linkage studies have identified linkage regions reaching the level of suggestive linkage at best (Freitag, 2007). Despite large increases in the size of patient cohorts, linkage signals have not increased significantly with sample size (Abrahams \& Geschwind, 2008). Only three loci (2q, 7q, and 17q11-17) have been replicated for nonsyndromic autism and are considered to have genome-wide significance. Genomic-wide screens have engendered great interest in chromosome $7 \mathrm{q}$ with distinctive peaks involving two distinct regions: 7q21-22 and 7q32-36 (International Molecular Genetic Study of Autism Consortium-IMGSAC, 1998; Collaborative Linkage Study of Autism, 2001). As chromosome 7q has been discussed in section "Cytogenetics: Rare Mutations," chromosome 2 and then 17q11 will follow the description of how linkage studies led to the discovery of the gene loci for a syndromic form of autism: tuberous sclerosis complex (TSC). The sibling-pair from multiplex family design has been used to study autism within many genetic loci, including those involved in TSC; the genomewide linkage analysis has detected linkage on chromosomes 7q, 2q, 17q11, and novel loci.

\section{Tuberous Sclerosis Complex}

Tuberous sclerosis complex (TSC) is a neurodevelopmental disorder characterized by cognitive delay, epilepsy, and neurocutaneous growths including hamartomas (i.e., tubers) within the central nervous system and other organs. Up to $60 \%$ of individuals with TSC have autism. The first suspicion of a chromosomal abnormality associated with TSC originated from a linkage study of 26 protein markers within 19 multigenerational families affected with TSC (Fryer et al., 1987). In eight of the families, ABO blood group gene mapped to chromosome 9q34.3. Many groups corroborated these results using larger numbers of families (Au, Williams, Gambello, \& Northrup, 2004). These linkage 
studies established the TSCl gene, later discovered to encode hamartin, a growth suppressor protein.

Another TSC gene site was discovered via linkage studies on chromosome 16p13.3, known as TSC2. This gene produces the tumor suppressor protein tuberin. Further evidence showed that hamartin works together with tuberin in several cell-signaling pathways including a growth and translation regulatory pathway $(\mathrm{P} 13 \mathrm{~K} / \mathrm{PKB})$, a cell adhesion/migration/protein transportation pathway [glycogen synthase kinase 3 (GSK3)/ $\beta$-catenin/focal adhesion kinase/Ras-related homolog (Rho) pathway], and a cell growth and proliferation pathway [mitogen-activated protein kinase (MAPK)]. The tuberin-hamartin complex affects mTOR kinase activity (Au et al., 2004), promoting tumor growth. This discovery has led to the study of rapamycin, a drug used in organ transplant and cancer treatment, as a therapy for suppressing growth of tumors in TSC (Kenerson, Aicher, True, \& Yeung, 2002).

Other growth-promoting genes such as PTEN have been linked to the tuberin-hamartin gene complex as contributors to the general overgrowth in TSC. As previously discussed, $P T E N$ is a gene of interest in autism.

\section{Chromosome 2q}

Buxbaum et al. (2007), together with the Seaver Autism Research Center (SARS), reported a two-point dominant LOD score of 2.25 on chromosome $2 \mathrm{q}$ in 35 affected sibling pairs. In a second-stage screening which employed 60 families with autism probands, the strongest linkage was at this same location. The IMGSAC study showed a strong linkage to $7 q$ as described above, but also found linkage to $2 q$ (IMGSAC, 1998), with a more recent study also providing evidence for linkage to 2q (IMGSAC, 2001b).

\section{Chromosome 17q}

Early recognition of the need for large patient cohorts and substantial genetic heterogeneity led to the establishment of the autism genetic resource exchange (AGRE) composed of over 500 families. AGRE is a publically available resource of phenotypic data and biomaterials. Genomic scan linkage analysis was performed on 109 autistic sibling pairs from 91 AGRE families together with analysis of those pairs from an independent sample of 345 families from the same AGRE cohort (Cantor et al., 2005). When families with autism were stratified into only those with affected males, there was significant linkage at 17q11-21 in both samples. The LOD score for this replicated work was at genome-wide level of significance (LOD score $>1.4$ ). One positional candidate gene close to this region is the serotonin transporter gene
(SLC6A4) which codes for a protein controlling the reuptake of serotonin in the synapse. This was exciting as elevated levels of serotonin have been determined in $25-30 \%$ of cases of autism (Cook et al., 1990). Indeed, relationship between the SLC6A4 site and a repeat polymorphic region in its promoter region (5HTTLPR) recently has been independently investigated (Losh et al., 2008). The chromosome 17q locus, however, has not been uniformly observed in subsequent, large-scale studies (Schellenberg et al., 2006) which may be due to phenotypic heterogeneity.

\section{Novel Loci for Autism}

A very recent genome-wide linkage mapping study in a sample of 1,031 multiplex autism families (Weiss, Arking, Daly, \& Chakravarti, 2009) identified significant linkage on chromosome 20p13 and suggestive linkage on chromosome $6 \mathrm{q} 27$. In this study, no associations meeting criteria for genome-wide significance were found, suggesting there are not many common loci of moderate to large effect size. However, replication data revealed a novel SNP locus on chromosome $5 \mathrm{p} 15$. This region was adjacent to SEMA5A, a member of the semaphoring axonal guidance protein family which has been shown to be downregulated in transformed B lymphocytes from autism samples (Weiss et al., 2009). The authors further demonstrated lower SEMA5A gene expression in autism brain tissue. This finding is in keeping with the suspected derangement in the migration of cortical neurons during embryogenesis in autism.

\section{Microarray Technology}

Microarray technology is transforming the identification of chromosome duplications and deletions (Gupta \& State, 2007). This new technology, known as high-density, oligonucleotide-based array comparative genomic hybridization $(\mathrm{aCGH})$, is now available for widespread use. This technique uses patient DNA and control DNA, each labeled with a fluorescent tag (red or green). Equal amounts of DNA from patient and control are hybridized to known regions of the human genome pre-arrayed on a slide. If patient and control have equal copy numbers at a given locus, the color turns yellow, representing an equal measure of DNA. If the patient has lost (deleted) a locus, only the control color is visualized. If the patient has an extra copy at a locus (duplication), the patient color predominates. The aCGH probe may be enriched for known genes or specific chromosomal regions for known syndromes, or distributed evenly across the whole genome. This new technique is now available at all major medical centers and through Signature Genomic Laboratories (www.signaturegenomics.com). 
Single-nucleotide polymorphism (SNP) analysis probes thousands of SNPs and provides data about copy number and genotype (Li \& Andersson, 2009). The genotype can be used to study uniparental disomy (UPI) seen in imprinting disorders and consanguinity. This technique is better at focused study of specific gene regions instead of the whole genome. Additionally, SNP analysis uses pre-established laboratory standards rather than intraexperimental controls. Both SNP analysis and aCGH map produce copy number variation, and it is common for labs to first perform aCGH and follow up with SNP in specific regions of interest.

Today, CNV from several thousand nucleotides can be identified, greatly improving upon the sensitivity of conventional cytogenetics. Sebat et al. (2007) showed that CNVs were present in $10 \%$ of affected individuals from singleincidence autism families (i.e., sporadic cases), contrasting with substantially lower rates observed in controls (1\%) and autism cases from multiplex families $(3 \%)$. This has led to the general expectation that de novo CNVs are more likely to be found in sporadic (and as it turns out, dysmorphic) cases. Jacquemont et al., 2006 reported CNV rearrangements in $8(27.5 \%)$ of 29 patients with syndromic autism (including facial dysmorphism, limb or visceral malformations, and growth abnormalities). There were no reoccurrence or overlap in these variants for the eight children. Chromosome 11q12-p13 and neurexins were implicated in a linkage study using SNP-CNV in 1,181 families with at least two affected individuals through the Autism Genome Project (Szatmari et al., 2007).

Microarray technology, however, comes with the realization that typically developing individuals have more structural variants than previously imagined (Sebat et al., 2007). There is growing concern that CNV irregularities may not be pathological and therefore not be a cause of autism (Tabor $\&$ Cho, 2007). These authors note that using diagnostic tools prematurely in a clinical context may be "unethical, either because of over-treatment, under-treatment, unwarranted labeling and stigmatization, or a false sense of security." Certainly, further studies on large cohorts of children with the same deletion/duplication are necessary to enable clinical application of this technology.

\section{Endophenotypes}

Due to the phenotypic heterogeneity of autism and the lack of finding a specific gene, researchers have narrowed the scope of analysis to more pure, operationally defined behaviors/traits. Endophenotypes are behavioral, physiological, and/or neuropsychological markers that are present in both affected and unaffected individuals. Rather than searching for "autism genes," endophenotype investigations search for smaller grouping of genes that contribute to discreet phenotypes (Losh et al., 2008). This approach allows for measurement of "dosage" of a trait and can be applied to affected as well as unaffected individuals.

\section{Specific Language Impairment}

Specific language impairment (SLI) is defined as the failure of normal development of language without hearing loss, mental retardation, or oral motor, neurological, or psychiatric impairment. This affects approximately $7 \%$ of children entering school (Tomblin et al., 1997). Individuals with SLI perform poorly on phonologically based tasks and many go on to develop dyslexia (Stothard, Snowling, Bishop, Chipchase, \& Kaplan, 1998). There appears to be neurostructural association between SLI and autism (Herbert et al., 2002; 2004), and there is an associated finding of language delay in relatives of probands with autism (Wassink et al., 2004). Several investigations have found strong linkage of SLI to chromosome 13q21 (Bartlett et al., 2002; 2004) and to chromosomes 16q and 19q (SLI Consortium, 2002, 2004). This finding is noteworthy as it directly overlies the $16 \mathrm{q}$ locus linked to autism (Wassink et al., 2004). A specific language marker, age of first word, has shown significant linkage to chromosome 7 observed by five separate investigators (Losh et al., 2008). The $7 q$ region has been the subject of intense investigation, as described above, and may be the loci associated with autism language.

\section{Restrictive and Repetitive Behavior}

The restricted and repetitive behavior (RRB) endophenotype in children with autism is receiving attention (Morgan, Wetherby, \& Barber, 2008). RRB comprises one prong of the autism clinical triad (language deficit, social deficit, and RRB). Cuccaro et al. (2003) identified two factors underlying RRB as measured by the Autism Diagnostic InterviewRevised (ADI-R): repetitive sensory motor actions and resistance to change. This is of interest as a genetic linkage signal has been reported for resistance to change on chromosome 15 (Shao et al., 2003). It appears that the analysis of phenotypic homogeneous subtypes may be a powerful tool for mapping of candidate genes in complex traits such as autism.

\section{Clinical Genetics Evaluation}

The recent marked increase in the incidence and awareness of autism has resulted in an increase in the number of children sent for diagnostic evaluation. The general consensus within the literature is that genetic consultation should be conducted on all persons with the confirmed diagnosis of 
autism. While referral for genetic consult is often preferred, often the primary practitioner, pediatrician, and/or pediatric neurologist are in a position to conduct the initial evaluation. Further, clinical geneticists may not be available, particularly in underserved areas of the country, or a timely genetic evaluation may not be possible due to lengthy waiting lists. Therefore, the clinician taking care of a child with autism may wish to initiate the genetic evaluation.

Recently, sequential guidelines for clinical genetics evaluation in autism have been published by Schaefer, Mendelsohn, and the Professional Practice and Guidelines Committee (2008) (see Box 6.5). These evidence-based guidelines have evolved from an original retrospective study of patients referred for clinical genetics evaluation between the years 2002 and 2004 at the University of Nebraska Medical Center (Schaefer \& Lutz, 2006). The guidelines are dynamic rather than static and have been updated, for example, as aCGH has become more available. The stepwise approach was designed to balance cost with the expected yield of the tests. Further, there is a pyramidal effect so that "earlier tiers have a greater expected diagnostic yield, lower invasiveness of testing, better potential of intervention, and easier overall practicality" (Schaefer \& Mendelsohn, 2008). Summarizing the diagnostic yields expected for the following investigations (high-resolution chromosome studies, 5\%; aCGH - beyond that detected by chromosome analysis - 10\%; fragile X, 5\%; MECP2, 5\% women only; PTEN, $3 \%$ if head circumference $>2.5 \mathrm{SD}$; other, $10 \%$ ), it was predicted that utilization of these guidelines would lead to diagnosis in $40 \%$ of cases (Schaefer, Mendelsohn, and the Professional Practice and Guidelines Committee (2008). Finally, this stepwise approach has met the approval of third-party payers and families (Schaefer \& Lutz, 2006).

\section{Box 6.5 Template for the Clinical Genetic Diagnostic} Evaluation of Autism Spectrum Disorders

Pre-evaluation

Confirmation of diagnosis of autism by trained professional using objective criteria and tools

Sensory screening (complete audiogram)

Electroencephalogram - if clinical suspicion of seizures

Cognitive testing

Verify results of newborn screening

(High-resolution chromosomal analysis and fragile $\mathrm{X}$ studies may be performed before referral)

\section{First tier}

Initial evaluation to identify known syndromes or associated conditions
Examination with special attention to dysmorphic features

Should include Wood's lamp evaluation

If specific diagnosis is suspected, proceed with targeted testing

Rubella titers - if clinical indicators present

"Standard" metabolic screening - if clinical indicators present and if suspected condition was not assessed by newborn screening

Urine mucopolysaccharides and organic acids

Serum lactate, amino acids, ammonia, and acylcarnitine profile

High-resolution chromosomal analysis - if not already performed.

\section{Second tier}

Fibroblast karyotype if leukocyte karyotype is normal and clonal pigmentary abnormalities are noted

Comparative genomic hybridization (chromosomal microarray)

$M E C P 2$ gene testing (females only)

PTEN gene testing (if head circumference is $2.5 \mathrm{SD}$ greater than the mean)

Third tier

Brain magnetic resonance imaging

Serum and urine uric acid

If elevated, hypoxanthine-guanine phosphoribosyltransferase (HgPRT) and

Phosphoribosylpyrophosphate (PRPP) synthetase superactivity testing

If low, purine/pyrimidine panel (uracil excretion, xanthine, and hypoxanthine)

If severe language deficit, check for Shank3 mutation*

Extracted from Shaefer, GB, Mendelsohn, NJ \& the Professional Practice and Guidelines Committee (2008). Clinical genetics evaluation in identifying the etiology of autism spectrum disorders. Genetics in Medicine, 10, 301-305 and used with the authors' permission.

*Recommended by Sokol and Lahiri

\section{Pre-evaluation}

This initial step includes confirming the diagnosis of autism using objective (DSM-IV) criteria and/or standardized objective measures such as those discussed in Chapter 15. An audiogram is obtained to rule out hearing loss and an electroencephalogram (EEG) is obtained if there is a clinical 
suspicion of seizures. Cognitive testing, when appropriate, can determine mental retardation. Finally, verifying the results of the newborn screen can help rule out rubella and PKU.

\section{Tier 1}

Initial assessment involves a standard clinical genetic history and physical exam to identify known syndromes or associated conditions. Included would be a Wood's lamp examination of the skin to help rule out neurocutaneous conditions such as TSC. Also, for suspected diagnoses, standard metabolic screening is performed to check for urine mucopolysaccharides and organic acids as well as serum lactate, amino acid, ammonia, and acylcarnitine profile. If not already performed, high-resolution chromosomal analysis and DNA for fragile $\mathrm{X}$ is sent.

\section{Tier 2}

If the studies in the first tier are unrevealing, the second tier checks for aCGH duplications and deletions. For patients with pigmentary abnormalities on exam but with a normal leukocyte karyotype, skin biopsy can be obtained to obtain a fibroblast karyotype. For females, MECP2 gene testing is obtained; for children with head circumference greater than 2.5 SD from the mean, PTEN gene testing is recommended.

\section{Tier 3}

Lower yield tests have been reserved for this level: brain magnetic resonance imaging and serum and urine uric acid. Further tests are outlined depending on the results (high or low) of the uric acid tests. We would add here that if a child has significant language impairment, a Shank3 mutation should be ruled out.

Finally, new susceptibility loci that can contribute to the autism phenotype are continually identified and catalogued in the Online Mendelian Inheritance in Man (OMIM) database (http//www.ncbi.nlm.nih.gov/sites/entrez). Using this search engine, a patient's phenotype including dysmorphic features can be entered into the program to generate a list of possible genetic diagnoses.

\section{Counseling}

Most clinical geneticists work with genetic counselors who interpret the findings into recurrent risks for full siblings. The tiered clinical genetics evaluation should identify two groups of individuals: those with and those without an identifiable etiology for autism. For those without an identifiable etiology, counseling should be provided according to multifactorial inheritance (Schaefer \& Mendelsohn, 2008). That is, $4 \%$ recurrence rate if the proband is a girl and $7 \%$ if the proband is a boy. If a second child has autism, a reasonable recurrence rate, based upon published reports, is $30 \%$.

Acknowledgment Thanks to Bryan Maloney, M.S. for his help in editing this manuscript.

\section{References}

Abrahams, B. S., \& Geschwind, D. H. (2008). Advances in autism genetics: On the threshold of a new neurobiology. Nature Reviews Genetics, 9(5), 341-355.

Alarcon, M., Abrahams, B. S., Stone, J. L., Duvall, J. A., Perederiy, J. V., Bomar, J. M., et al. (2008). Linkage, association, and geneexpression analyses identify CNTNAP2 as an autism-susceptibility gene. American Journal of Human Genetics, 82(1), 150-159.

Alley, G. M., Bailey, J. A., Chen, D. -M., Ray, B., Puli, L. K., Tanila, H., et al. (2010). Memantine lowers amyloid-beta peptide levels in neuronal cultures and in APP/PS1 transgenic mice. Journal of Neuroscience Research, 88, 143-154.

Ashley-Koch, A. E., Jaworski, J., Ma de, Q., Mei, H., Ritchie, M. D., Skaar, D. A., et al. (2007). Investigation of potential gene-gene interactions between APOE and RELN contributing to autism risk Psychiatric Genetics, 17, 221-226.

Au, K. S., Williams, A. T., Gambello, M. J., \& Northrup, H. (2004). Molecular genetic basis of tuberous sclerosis complex: From bench to bedside. Journal of Child Neurology, 19, 699-709.

Bailey, A. R., Giunta, B. N., Obregon, D., Nikolic, W. V., Tian, J., Sanberg, C. D., et al. (2008). Peripheral biomarkers in autism: Secreted amyloid precursor protein-alpha as a probable key player in early diagnosis. International Journal of Clinical Experimental Medicine, 1, 338-344.

Bailey, A., Le Couteur, A., Gottesman, I., Bolton, P., Simonoff, E., Yuzda, E., et al. (1995). Autism as a strongly genetic disorder: Evidence from a British twin study. Psychological Medicine, 25, 63-77.

Bakkaloglu, B., O’Roak, B. J., Louvi, A., Gupta, A. R., Abelson, J. F., Morgan, T. M., et al. (2008). Molecular cytogenetic analysis and resequencing of contactin associated protein-like 2 in autism spectrum disorders. American Journal of Human Genetics, 82, 165-173.

Bartlett, C. W., Flax, J. F., Logue, M. W., Smith, B. J., Vieland, V. J., Tallal, P., et al. (2004). Examination of potential overlap in autism and language loci on chromosomes 2, 7, and 13 in two independent samples ascertained for specific language impairment. Human Hereditary, 57, 10-20.

Bartlett, C. W., Flax, J. F., Logue, M. W., Vieland, V. J., Bassett, A. S., Tallal, P., et al. (2002). A major susceptibility locus for specific language impairment is located on 13q21. American Journal of Human Genetics, 71, 45-55.

Basehore, M. J., \& Friez, M. J. (2009). Molecular Analysis of Fragile X Syndrome. Current Protocols in Human Genetics, 63 (Chapter 9 , Unit 9).

Bear, M. F. (2005). Therapeutic implications of the mGluR theory of fragile X mental retardation. Genes Brain \& Behavior, 4, 393-398.

Bear, M. F., Huber, K. M., \& Warren, S. T. (2004). The mGluR theory of fragile X mental retardation. Trends in Neuroscience, 27, 370-377. 
Berry-Kravis, E., Potanas, K., Weinberg, D., Zhou, L., \& Goetz, C. G. (2005). Fragile X-associated tremor/ataxia syndrome in sisters related to X-inactivation. Annals of Neurology, 57, 144-147.

Butler, M. G., Dasouki, M. J., Zhou, X. P., Talebizadeh, Z., Brown, M., Takahashi, T. N., et al. (2005). Subset of individuals with autism spectrum disorders and extreme macrocephaly associated with germline PTEN tumour suppressor gene mutations. Journal of Medical Genetics, 42, 318-321.

Buxbaum, J. D., Cai, G., Chaste, P., Nygren, G., Goldsmith, J., Reichert, J., et al. (2007). Mutation screening of the PTEN gene in patients with autism spectrum disorders and macrocephaly. American Journal of Medical Genetics, 144B, 484-491.

Cantor, R. M., Kono, N., Duvall, J. A., Alvarez-Retuerto, A., Stone, J. L., Alarcon, M., et al. (2005). Replication of autism linkage: Finemapping peak at 17q21. American Journal of Human Genetics, 76, 1050-1056.

Collaborative Linkage Study of Autism (CLSA). (1999). An autosomal genomic screen for autism. American Journal of Medical Genetics, $88,609-615$.

Collaborative Linkage Study of Autism. (2001). An autosomal genomic screen for autism. American Journal of Medical Genetics, 105, 609-615

Cook, E. H., Jr., Leventhal, B. L., Heller, W., Metz, J., Wainwright, M., \& Freedman, D. X. (1990). Autistic children and their first degree relatives: Relationships between serotonin and norepinephrine levels and intelligence. The Journal of Neuropsychiatry and Clinical Neurosciences, 2, 268-274.

Cook, E. H., Jr., Lindgren, V., Leventhal, B. L., Courchesne, R., Lincoln, A., Shulman, C., et al. (1997). Autism or atypical autism in maternally but not paternally derived proximal $15 \mathrm{q}$ duplication. American Journal of Human Genetics, 60, 928-934.

Costa e Silva, J. A. (2008). Autism, a brain developmental disorder: Some new pathophysiologic and genetics findings. Metabolism, 57(Suppl 2), S40-S43.

Courchesne, E., Carper, R., \& Akshoomoff, N. (2003). Evidence of brain overgrowth in the first year of life in autism. Journal of the American Medical Association, 290, 337-344.

Courchesne, E., Karns, C. M., Davis, H. R., Ziccardi, R., Carper, R. A., Tigue, Z. D., et al. (2001). Unusual brain growth patterns in early life in patients with autistic disorder: An MRI study. Neurology, 57, 245-254.

Cuccaro, M. L., Shao, Y., Grubber, J., Slifer, M., Wolpert, C. M., Donnelly, S. L., et al. (2003). Factor analysis of restricted and repetitive behaviors in autism using the autism diagnostic interview-R. Child Psychiatry and Human Development, 34, 3-17.

DiCicco-Bloom, E. (2006). Neuron, know thy neighbor. Science, 311, $1560-1562$.

Dolen, G., Osterweil, E., Rao, B. S., Smith, G. B., Auerbach, B. D., Chattarji, S., et al. (2007). Correction of fragile X syndrome in mice. Neuron, 59, 955-962.

Durand, C. M., Betancur, C., Boeckers, T. M., Bockmann, J., Chaste, P., Fauchereau, F., et al. (2007). Mutations in the gene encoding the synaptic scaffolding protein SHANK3 are associated with autism spectrum disorders. Nature Genetics, 39, 25-27.

D’Agata, V., Warren, S. T., Zhao, W., Torre, E. R., Alkon, D. L., \& Cavallaro, S. (2002). Gene expression profiles in a transgenic animal model of fragile X syndrome. Neurobiology of Disease, 10, 211-218.

Einfeld, S., Molony, H., \& Hall, W. (1989). Autism is not associated with the fragile X syndrome. American Journal of Medical Genetics, 34, 187-193.

Etherton, M. R., Blaiss, C. A., Powell, C. M., \& Sudhof, T. C. (2009). Mouse neurexin-1alpha deletion causes correlated electrophysiological and behavioral changes consistent with cognitive impairments. Proceedings of the National Academy of Sciences, 106, 17998-18003.
Feng, J., Schroer, R., Yan, J., Song, W., Yang, C., Bockholt, A., et al. (2006). High frequency of neurexin 1beta signal peptide structural variants in patients with autism. Neuroscience Letters, 409, 10-13.

Folstein, S., \& Rutter, M. (1977). Infantile autism: A genetic study of 21 twin pairs. Journal of Child Psychology and Psychiatry, 18, 297-321.

Freitag, C. M. (2007). The genetics of autistic disorders and its clinical relevance: A review of the literature. Molecular Psychiatry, 12, $2-22$.

Fryer, A. E., Chalmers, A., Connor, J. M., Fraser, I., Povey, S., Yates, A. D., et al. (1987). Evidence that the gene for tuberous sclerosis is on chromosome 9. Lancet, 1, 659-661.

Geschwind, D. H. (2009). Advances in autism. Annual Review of Medicine, 60, 367-380.

Geschwind, D. H., \& Konopka, G. (2009). Neuroscience in the era of functional genomics and systems biology. Nature, 461, 908-915.

Glessner, J. T., Wang, K., Cai, G., Korvatska, O., Kim, C. E., Wood, S., et al. (2009). Autism genome-wide copy number variation reveals ubiquitin and neuronal genes. Nature, 459, 569-573.

Gupta, A. R., \& State, M. W. (2007). Recent advances in the genetics of autism. Biological Psychiatry, 61, 429-437.

Hagerman, R. J. (2002). The physical and behavioral phenotype. In R. J. Hagerman \& P. J. Hagerman (Eds.), Fragile X syndrome: Diagnosis, treatment, and research (3rd ed., pp. 3-109). Baltimore: Johns Hopkins University Press.

Hagerman, R. J. (2006). Lessons from fragile X regarding neurobiology, autism, and neurodegeneration. Journal of Developmental Behavioral Pediatrics, 27, 63-74.

Hagerman, R. J., Leehey, M., Heinrichs, W., Tassone, F., Wilson, R., Hills, J., et al. (2001). Intention tremor, parkinsonism, and generalized brain atrophy in male carriers of fragile X. Neurology, 57, $127-130$.

Herbert, M. R., Harris, G. J., Adrien, K. T., Ziegler, D. A., Makris, N., Kennedy, D. N., et al. (2002). Abnormal asymmetry in language association cortex in autism. Annals of Neurology, 52, 588-596.

Herbert, M. R., Ziegler, D. A., Makris, N., Filipek, P. A., Kemper, T. L., Normandin, J. J., et al. (2004). Localization of white matter volume increase in autism and developmental language disorder. Annals of Neurology, 55, 530-540.

Herman, G. E., Butter, E., Enrile, B., Partore, M., Prior, T. W., \& Sommer, A. (2007b). Increasing knowledge of PTEN germline mutations: Two additional patients with autism and macrocephaly. American Journal of Medical Genetics, 143, 589-593.

Herman, G. E., Henninger, N., Ratliff-Schaub, K., Pastore, M., Fitzgerald, S., \& MCBride, K. L. (2007a). Genetic testing in autism: How much is enough? Genetics in Medicine, 9, 268-273.

International HapMap Consortium. (2005). A haplotype map of the human genome. Nature, 437, 1299-1320.

International Molecular Genetic Study of Autism Consortium (IMGSAC). (1998). A full genome screen for autism with evidence for linkage to a region on chromosome 7q. International molecular genetic study of autism consortium. Human Molecular Genetics, 7 , 571-578.

International Molecular Genetic Study of Autism Consortium (IMGSAC). (2001a). Further characterization of the autism susceptibility locus AUTS1 on chromosome 7q. Human Molecular Genetics, 10, 973-982.

International Molecular Genetic Study of Autism Consortium (IMGSAC). (2001b). A genomewide screen for autism: Strong evidence for linkage to chromosomes 2q, 7q, and 16p. American Journal of Human Genetics, 69, 570-581.

Jackman, C., Horn, N. D., Molleston, J. P., \& Sokol, D. K. (2009). Gene associated with seizures, autism, and hepatomegaly in an Amish girl. Pediatric Neurology, 40, 310-313.

Jacquemont, M. L., Sanlaville, D., Redon, R., Raoul, O., Cormier-Daire, V., Lyonnet, S., et al. (2006). Array-based comparative genomic 
hybridisation identifies high frequency of cryptic chromosomal rearrangements in patients with syndromic autism spectrum disorders. Journal of Medical Genetics, 43, 843-849.

Jamain, S., Quach, H., Betancur, C., Rastam, M., Colineaux, C., Gillberg, I. C., et al. (2003). Mutations of the X-linked genes encoding neuroligins NLGN3 and NLGN4 are associated with autism. Nature Genetics, 34, 27-29.

Kenerson, H. L., Aicher, L. D., True, L. D., \& Yeung, R. S. (2002). Activated mammalian target of rapamycin pathway in the pathogenesis of tuberous sclerosis complex renal tumors. Cancer Research, $62,5645-5650$.

Konopka, G., Bomar, J. M., Winden, K., Coppola, G., Jonsson, Z. O., Gao, F., et al. (2009). Human-specific transcriptional regulation of CNS development genes by FOXP2. Nature, 462, 213-217.

Kwon, C. H., Luikart, B. W., Powell, C. M., Zhou, J., Matheny, S. A., Zhang, W., et al. (2006). Pten regulates neuronal arborization and social interaction in mice. Neuron, 50, 377-388.

Lahiri, D. K., Farlow, M. R., Greig, N. H., Giacobini, E., \& Schneider, L. S. (2003). A critical analysis of new molecular targets and strategies for drug developments in Alzheimer's disease. Current Drug Targets, 4, 97-112.

Lahiri, D. K., Maloney, B., \& Zawia, N. H. (2009). The LEARn model: An epigenetic explanation for idiopathic neurobiological diseases. Molecular Psychiatry, 14, 992-1003.

Lai, C. S., Fisher, S. E., Hurst, J. A., Vargha-Khadem, F., \& Monaco, A. P. (2001). A forkhead-domain gene is mutated in a severe speech and language disorder. Nature, 413, 519-523.

Lander, E., \& Kruglyak, L. (1995). Genetic dissection of complex traits: Guidelines for interpreting and reporting linkage results. Nature Genetics, 11, 241-247.

Lander, E. S., Linton, L. M., Birren, B., Nusbaum, C., Zody, M. C., Baldwin, J., et al. (2001). Initial sequencing and analysis of the human genome. Nature, 409, 860-921.

Laumonnier, F., Bonnet-Brilhault, F., Gomot, M., Blanc, R., David, A., Moizard, M. P., et al. (2004). X-linked mental retardation and autism are associated with a mutation in the NLGN4 gene, a member of the neuroligin family. American Journal of Human Genetics, 74, $552-557$.

Lawson-Yuen, A., Saldivar, J. S., Sommer, S., \& Picker, J. (2008). Familial deletion within NLGN4 associated with autism and Tourette syndrome. European Journal of Human Genetics, 16, 614-618.

Li, M. M., \& Andersson, H. C. (2009). Clinical application of microarray-based molecular cytogenetics: An emerging new era of genomic medicine. Journal of Pediatrics, 155, 311-317.

Li, J., Nguyen, L., Gleason, C., Lotspeich, L., Spiker, D., Risch, N., et al. (2004). Lack of evidence for an association between WNT2 and RELN polymorphisms and autism. American Journal of Medical Genetics, 126B, 51-57.

Lien, W. H., Klezovitch, O., \& Vasioukhin, V. (2006). Cadherin-catenin proteins in vertebrate development. Current Opinion Cell Biology, 18, 499-506.

Lintas, C., \& Persico, A. M. (2009). Autistic phenotypes and genetic testing: State-of-the-art for the clinical geneticist. Journal of Medical Genetics, 46, 1-8.

Losh, M., Sullivan, P. F., Trembath, D., \& Piven, J. (2008). Current developments in the genetics of autism: From phenome to genome. Journal of Neuropathological Exp Neurology, 67, 829-837.

Lubs, H. A. (1969). A marker X chromosome. Am J Hum Genet, 21(3), 231-244.

Maes, B., Fryns, J. P., Van Walleghem, M., \& Van den Berghe, H. (1993). Fragile-X syndrome and autism: A prevalent association or a misinterpreted connection? Genetic Counseling, 4, 245-263.

Mahr, R. N., Moberg, P. J., Overhauser, J., Strathdee, G., Kamhoampbell, J., Loevner, L. A. et al. (1996). Neuropsychiatry of 18q-. American Journal of Medical Genetics, 67, 172C-178C.
Marco, E. J., \& Skuse, D. H. (2006). Autism-lessons from the X chromosome. Social Cognitive and Affective Neuroscience, 1, 183-193.

Marshall, C. R., Noor, A., Vincent, J. B., Lionel, A. C., Feuk, L., Skaug, J., et al. (2008). Structural variation of chromosomes in autism spectrum disorder. American Journal of Human Genetics, $82,477-488$

Mattson, M. P., \& Furukawa, K. (1998). Signaling events regulating the neurodevelopmental triad. Glutamate and secreted forms of beta-amyloid precursor protein as examples. Perspectives on Developmental Neurobiology, 5, 337-352.

McCaffery, P., \& Deutsch, C. K. (2005). Macrocephaly and the control of brain growth in autistic disorders. Progress in Neurobiology, 77, $38-56$.

Mendelsohn, N. J., \& Schaefer, G. B. (2008). Genetic evaluation of autism. Seminars in Pediatric Neurology, 15, 27-31.

Moessner, R., Marshall, C. R., Sutcliffe, J. S., Skaug, J., Pinto, D., Vincent, J., et al. (2007). Contribution of SHANK3 mutations to autism spectrum disorder. American Journal of Medical Genetics, $81,1289-1297$.

Morgan, L., Wetherby, A. M., \& Barber, A. (2008). Repetitive and stereotyped movements in children with autism spectrum disorders late in the second year of life. Journal of Child Psychology \& Psychiatry, 49, 826-837.

Morrow, E. M., Yoo, S. Y., Flavell, S. W., Kim, T. K., Lin, Y., Hill, R. S., et al. (2008). Identifying autism loci and genes by tracing recent shared ancestry. Science, 321, 218-223.

Muhle, R., Trentacoste, S. V., \& Rapin, I. (2004). The genetics of autism. Pediatrics, 113, 472-486.

Newbury, D. F., Bonora, E., Lamb, J. A., Fisher, S. E., Lai, C. S., Baird, G., et al. (2002). FOXP2 is not a major susceptibility gene for autism or specific language impairment. American Journal of Human Genetics, 70, 1318-1327.

O’Brien, E. K., Zhang, X., Nishimura, C., Tomblin, J. B., \& Murray, J. C. (2003). Association of specific language impairment (SLI) to the region of 7q31. American Journal of Human Genetics, 72, 1536-1543.

O'Roak, B. J., \& State, M. W. (2008). Autism genetics: Strategies, challenges, and opportunities. Autism Research, 1, 4-17.

Pack, P. (2002). Biology (Cliffs AP) (2nd ed.). Hoboken, NJ: Wiley.

Pennington, B. F. (2009). Diagnosing learning disorders: A neuropsychological framework. New York: Guilford Press.

Persico, A. M., Pascucci, T., Puglisi-Allegra, S., Militerni, R., Bravaccio, C., Schneider, C., et al. (2002). Serotonin transporter gene promoter variants do not explain the hyperserotonemia in autistic children. Molecular Psychiatry, 7, 795-800.

Pickles, A., Bolton, P., Macdonald, H., Bailey, A., Le Couteur, A., Sim, C. H., et al. (1995). Latent-class analysis of recurrence risks for complex phenotypes with selection and measurement error: A twin and family history study of autism. American Journal of Human Genetics, 57, 717-726.

Piven, J. (1999). Genetic liability for autism: The behavioral expression in relatives. International Review of Psychiatry, 11, 299-308.

Reichenberg, A., Gross, R., Weiser, M., Bresnahan, M., Silverman, J., Harlap, S., et al. (2006). Advancing paternal age and autism. Archives of General Psychiatry, 63, 1026-1032.

Rutter, M. (2000). Genetic studies of autism: From the 1970s into the millennium. Journal of Abnormal Child Psychiatry, 28, 3-14.

Schaefer, G. B., \& Lutz, R. E. (2006). Diagnostic yield in the clinical genetics evaluation of autism spectrum disorders. Genetics in Medicine, 8, 549-556.

Schaefer, G. B., \& Mendelsohn, N. J. (2008). Genetics evaluation for the etiologic diagnosis of autism spectrum disorders. Genetics in Medicine, 10, 4-12.

Schaefer, G. B., \& Mendelsohn, N. J., Professional Practice and Guidelines Committee. (2008). Clinical genetics evaluation in 
identifying the etiology of autism spectrum disorders. Genetics in Medicine, 10, 301-305.

Schellenberg, G. D., Dawson, G., Sung, Y. J., Estes, A., Munson, J., Rosenthal, E., et al. (2006). Evidence for multiple loci from a genome scan of autism kindreds. Molecular Psychiatry, 11, 10491060.

Schroer, R. J., Phelan, M. C., Michaelis, R. C., Crawford, E. C., Skinner, S. A., Cuccaro, M., et al. (1998). Autism and maternally derived aberrations of chromosome 15q. American Journal of Medical Genetics, 76, 327-336.

Sebat, J., Lakshmi, B., Malhotra, D., Troge, J., Lese-Martin, C., Walsh, T., et al. (2007). Strong association of de novo copy number mutations with autism. Science, 316, 445-449.

Shao, Y., Cuccaro, M. L., Hauser, E. R., Raiford, K. L., Menold, M. M., Wolpert, C. M., et al. (2003). Fine mapping of autistic disorder to chromosome 15q11-q13 by use of phenotypic subtypes. American Journal of Medical Genetics, 72, 539-548.

SLI Consortium. (2002). A genomewide scan identifies two novel loci involved in specific language impairment. American Journal of Human Genetics, 70, 384-398.

SLI Consortium. (2004). Highly significant linkage to the SLI1 locus in an expanded sample of individuals affected by specific language impairment. American Journal of Human Genetics, 74, $1225-1238$.

Smith, S. D. (2007). Genes, language development, and language disorders. Mental Retardation and Developmental Disabilities Research Reviews, 13, 96-105.

Sokol, D. K., Chen, D., Farlow, M. R., Dunn, D. W., Maloney, B., Zimmer, J. A., et al. (2006). High levels of Alzheimer beta-amyloid precursor protein (APP) in children with severely autistic behavior and aggression. Journal of Child Neurology, 21, 444-449.

Sokol, D. K., \& Edwards-Brown, M. (2004). Neuroimaging in autistic spectrum disorder (ASD). Journal of Neuroimaging, 14, 8-15.

Solomon, E., Berg, L., \& Martin, D. W. (2008). Biology (8th ed.). San Francisco: BrooksCole.

Sparks, B. F., Friedman, S. D., Shaw, D. W., Aylward, E. H., Echelard, D., Artru, A. A., et al. (2002). Brain structural abnormalities in young children with autism spectrum disorder. Neurology, 59, 184-192.

Steffenburg, S., Gillberg, C., Hellgren, L., Andersson, L., Gillberg, I. C., Jakobsson, G., et al. (1989). A twin study of autism in Denmark, Finland, Iceland, Norway and Sweden. Journal Child Psychology \& Psychiatry, 30, 405-416.

Stothard, S. E., Snowling, M. J., Bishop, D. V., Chipchase, B. B., \& Kaplan, C. A. (1998). Language-impaired preschoolers: A followup into adolescence. Journal of Speech, Language, and Hearing Research, 41, 407-418.

Strauss, K. A., Puffenberger, E. G., Huentelman, M. J., Gottlieb, S., Dobrin, S. E., Parod, J. M., et al. (2006). Recessive symptomatic focal epilepsy and mutant contactin-associated protein-like 2. New England Journal of Medicine, 354, 1370-1377.
Sykes, N. H., \& Lamb, J. A. (2007). Autism: The quest for the genes. Expert Reviews in Molecular Medicine, 9, 1-15.

Szatmari, P., Paterson, A. D., Zwaigenbaum, L., Roberts, W., Brian, J., Liu, X. Q., et al. (2007). Mapping autism risk loci using genetic linkage and chromosomal rearrangements. Nature Genetics, 39, 319-328.

Tabor, H. K., \& Cho, M. K. (2007). Ethical implications of array comparative genomic hybridization in complex phenotypes: Points to consider in research. Genetics in Medicine, 9, 626-631.

Tomblin, J. B., Records, N. L., Buckwalter, P., Zhang, X., Smith, E., \& O'Brien, M. (1997). Prevalence of specific language impairment in kindergarten children. Journal of Speech, Language and Hearing Research, 40, 1245-1260.

Veenstra-VanderWeele, J., \& Cook, E. H., Jr. (2004). Molecular genetics of autism spectrum disorder. Molecular Psychiatry, 9, 819-832.

Vincent, J. B., Petek, E., Thevarkunnel, S., Kolozsvari, D., Cheung, J., Patel, M., et al. (2002). The RAY1/ST7 tumor-suppressor locus on chromosome $7 \mathrm{q} 31$ represents a complex multi-transcript system. Genomics, 80, 283-294.

Volpe, J. J. (2001). Neurology of the newborn (4th ed.). Philadelphia: WB Saunders.

Vorstman, J. A., Staal, W. G., van Daalen, E., van Engeland, H., Hochstenbach, P. F., \& Franke, L. (2006). Identification of novel autism candidate regions through analysis of reported cytogenetic abnormalities associated with autism. Molecular Psychiatry, 11(1), 18-28.

Wassink, T. H., Brzustowicz, L. M., Bartlett, C. W., \& Szatmari, P. (2004). The search for autism disease genes. Mental Retardation Developmental Disabilities Research Review, 10, 272-283.

Wassink, T. H., Piven, J., Vieland, V. J., Huang, J., Swiderski, R. E., Pietila, J., et al. (2001). Evidence supporting WNT2 as an autism susceptibility gene. American Journal of Medical Genetics, 105, 406-413.

Weiss, L. A., Arking, D. E., Daly, M. J., \& Chakravarti, A. (2009). A genome-wide linkage and association scan reveals novel loci for autism. Nature, 461, 802-808.

Westmark, C. J., \& Malter, J. S. (2007). FMRP mediates mGluR5dependent translation of amyloid precursor protein. Public Library of Science Biology, 5, e52.

Yan, D., Oliveira, G., Coutinho, A., Yang, C., Feng, J., Katz, C., et al. (2005). Analysis of the neuroligin 3 and 4 genes in autism and other neuropsychiatric patients. Molecular Psychiatry, 10, 329-332.

Zhang, H., Liu, X., Zhang, C., Mundo, E., Macciardi, F., Grayson, D. R., et al. (2002). Reelin gene alleles and susceptibility to autism spectrum disorders. Molecular Psychiatry, 7, 1012-1017.

Zoghbi, H. Y. (2003). Postnatal neurodevelopmental disorders: Meeting at the synapse? Science, 302, 826-830. 